\title{
Evidence for the Management of Bronchopulmonary Dysplasia in Very Preterm Infants
}

\author{
Tobias Muehlbacher * $\mathbb{D}$, Dirk Bassler and Manuel B. Bryant \\ Department of Neonatology, University Hospital Zurich, 8091 Zurich, Switzerland; dirk.bassler@usz.ch (D.B.); \\ manuel.bryant@usz.ch (M.B.B.) \\ * Correspondence: tobias.muehlbacher@usz.ch
}

check for updates

Citation: Muehlbacher, T.; Bassler, D.; Bryant, M.B. Evidence for the Management of Bronchopulmonary Dysplasia in Very Preterm Infants. Children 2021, 8, 298. https:// doi.org/10.3390/children8040298

Academic Editor: Elizabeth Asztalos

Received: 10 March 2021

Accepted: 9 April 2021

Published: 13 April 2021

Publisher's Note: MDPI stays neutral with regard to jurisdictional claims in published maps and institutional affiliations.

Copyright: (c) 2021 by the authors. Licensee MDPI, Basel, Switzerland. This article is an open access article distributed under the terms and conditions of the Creative Commons Attribution (CC BY) license (https:/ / creativecommons.org/licenses/by/ $4.0 /)$.

\begin{abstract}
Background: Very preterm birth often results in the development of bronchopulmonary dysplasia (BPD) with an inverse correlation of gestational age and birthweight. This very preterm population is especially exposed to interventions, which affect the development of BPD. Objective: The goal of our review is to summarize the evidence on these daily procedures and provide evidencebased recommendations for the management of BPD. Methods: We conducted a systematic literature research using MEDLINE/PubMed on antenatal corticosteroids, surfactant-replacement therapy, caffeine, ventilation strategies, postnatal corticosteroids, inhaled nitric oxide, inhaled bronchodilators, macrolides, patent ductus arteriosus, fluid management, vitamin A, treatment of pulmonary hypertension and stem cell therapy. Results: Evidence provided by meta-analyses, systematic reviews, randomized controlled trials (RCTs) and large observational studies are summarized as a narrative review. Discussion: There is strong evidence for the use of antenatal corticosteroids, surfactant-replacement therapy, especially in combination with noninvasive ventilation strategies, caffeine and lung-protective ventilation strategies. A more differentiated approach has to be applied to corticosteroid treatment, the management of patent ductus arteriosus (PDA), fluid-intake and vitamin A supplementation, as well as the treatment of BPD-associated pulmonary hypertension. There is no evidence for the routine use of inhaled bronchodilators and prophylactic inhaled nitric oxide. Stem cell therapy is promising, but should be used in RCTs only.
\end{abstract}

Keywords: bronchopulmonary dysplasia; chronic lung disease; prevention; treatment; preterm infant

\section{Introduction}

Bronchopulmonary dysplasia (BPD) is one of the most common morbidities in very preterm infants. In 1967, Northway introduced the term "bronchopulmonary dysplasia" for the fibrotic pulmonary remodeling of preterm infants after respiratory distress syndrome [1]. The definition of BPD changed since Northway's definition of oxygen demand at 28 days of life: first, to the oxygen requirement at 36 weeks postmenstrual age (PMA) [2] and, then, to the "new" (in the cited studies most commonly used) criteria of the National Institutes of Child Health and Human Development (NICHD)/National Heart, Lung, and Blood Institute (NHLBI) workshop of 2001 that was developed with the purpose of identifying affected patients in a more precise way and quantifying the severity of the disease [3]. The latter defines BPD as oxygen demand at 28 days of life and a stratification of severity at 36 weeks PMA by the need for supplemental oxygen and respiratory support (Table 1). However, the definition of BPD is still a matter of ongoing debate regarding the changes in neonatal care during the last decades, e.g., the widespread use of a nasal cannula with different flow settings [4]. The incidence of BPD ranges from 10\% to $40 \%$, with an inverse correlation with gestational age and birthweight [5]. As neonatal intensive care substantially improved, the mortality rate of preterm infants decreased; however, the rates of $\mathrm{BPD}$ remained basically the same or even increased as more immature infants survived [6,7]. Addressing the change in the pathophysiological mechanism of BPD development, Jobe coined the term "new" BPD for an altered lung development in these 
extremely preterm infants in contrast to the pre-surfactant lung injury to oxygen toxicity and aggressive mechanical ventilation [8]. A complex mixture of developmental plasticity, inflammation, injury and repair of the immature lungs leads to the clinical entity "BPD" with altered alveolarization and vascularization [9]. It is associated with long-term sequelae as persistent respiratory symptoms, impaired lung function, pulmonary hypertension and adverse neurodevelopmental outcomes and is therefore associated with increased rates of rehospitalization and late mortality $[4,5,10,11]$. As no "silver bullet" for the prevention or treatment of BPD exists, it is essential to apply a multifactorial approach to the management of BPD in very preterm infants. This review focuses on everyday strategies regarding the management of BPD and on controversially discussed interventions and their impact on developing BPD.

Table 1. Bronchopulmonary dysplasia (BPD) definition by the criteria of the National Institutes of Child Health and Human Development (NICHD)/National Heart, Lung, and Blood Institute (NHLBI) workshop of 2001 [3].

\begin{tabular}{|c|c|}
\hline BPD Severity & Criteria \\
\hline mild & $\begin{array}{l}\text { Supplemental oxygen on } 28 \text { th day of life and no supplemental } \\
\text { oxygen at } 36 \text { weeks PMA }\end{array}$ \\
\hline moderate & Supplemental oxygen of $>21 \%$ but $<30 \%$ at 36 weeks PMA \\
\hline severe & $\begin{array}{c}\text { Supplemental oxygen }>30 \% \text { or positive airway pressure or } \\
\text { mechanical ventilation at } 36 \text { weeks PMA }\end{array}$ \\
\hline
\end{tabular}

PMA: postmenstrual age.

\section{What Is the Evidence for?}

\subsection{Antenatal Corticosteroids}

Prophylactic treatment with antenatal corticosteroids (ANS) to accelerate lung maturation has been first described by Liggins and Howie in a randomized controlled trial (RCT) in 1972 aiming at the severity of respiratory distress syndrome [12]. The effect on an additionally decreased neonatal mortality and other morbidities in a systematic review [13] led to the NIH consensus paper recommending antenatal corticosteroids for impending preterm birth from 24 weeks to 34 weeks of gestation [14]. The most common regimens consist of two doses of intramuscular injection of 12-mg betamethasone $24 \mathrm{~h}$ apart or four doses of 6-mg betamethasone every $12 \mathrm{~h} \mathrm{[15].} \mathrm{A} \mathrm{recent} \mathrm{meta-analysis} \mathrm{included} 30$ randomized controlled trials with 8158 preterm infants that confirmed the previous findings with a reduction of perinatal death (relative risk (RR) $0.72,95 \%$ confidence interval (CI) $0.58-0.89, n=6729$ ), but no reduction of BPD could be shown (RR $0.86,95 \%$ CI $0.42-1.79$, $n=818$ ) [16]. A similar result has been shown by large prospective population-based observational studies [17-19] and by a meta-analysis of studies involving small for gestational age infants [20]. However, the before mentioned Cochrane review did not evaluate the effects of ANS in extremely preterm infants due to a lack of sufficient data in RCTs. A meta-analysis of observational studies analyzing these particular infants born before 25 weeks of gestation also found a highly significant reduction in mortality (odds ratio (OR) $0.48,95 \%$ CI $0.42-0.55, n=13,443$ ) [21]. The BPD rate was higher in this study (OR 1.32, $95 \%$ CI 1.04-1.67, $n=7983)$, but the composite outcome of BPD and death was reduced by the use of ANS (OR $0.58,95 \%$ CI $0.42-0.79, n=11782$ ) [21]. The results reflected the competitive outcomes of mortality and bronchopulmonary dysplasia in extremely preterm infants. Two further population-based studies not included in the meta-analysis showed a higher BPD rate and lower mortality as well but did not report on the composite outcome [22,23]. Others could show a reduction of both BPD and the mortality rates [24-26]. The overall efficiency of ANS depends on the optimum timing of the ANS. Exposure to a completed course of ANS with an interval from $24 \mathrm{~h}$ up to seven days after the last injection is the most effective strategy $[23-25,27,28]$. An incomplete course or an interval longer than seven days was less efficient, nonetheless resulting in a better outcome than 
no exposure to ANS $[23,25,27,28]$. Another Cochrane review analyzed whether (weekly) repeated courses of ANS are beneficial compared to a single course. They could show a reduction of severe respiratory distress syndrome, yet without an effect on the long-term morbidity or mortality [29]. A post-hoc analysis of a multicenter trial showed a higher mortality in infants of mothers treated with three or more courses of ANS [30].

\subsection{Surfactant Replacement Therapy}

The introduction of surfactant replacement therapy in preterm infants with respiratory distress syndrome by Fujiwara et al. 1980 was a game-changing event in neonatal medicine [31]. The regular administration of surfactant in preterm infants led to the change from the "old" to "new" bronchopulmonary dysplasia [8]. Multiple meta-analyses on the RCTs of the 1990s showed a reduction of the overall mortality and, especially, mortality due to respiratory distress syndrome by surfactant replacement therapy [32-36]. However, no effect could be shown on the incidence of BPD, as now more and, especially, more immature babies survived. Different types of surfactant have proven effective in the treatment of respiratory distress syndrome and the reduction of mortality: synthetic surfactants containing surfactant proteins [37] or protein-free formulation [35] and animal-derived surfactants [36]. A meta-analysis could show a slight superiority of animal-derived surfactants compared to protein-free surfactants regarding mortality (RR $0.89,95 \%$ CI $0.79-0.99, n=5413$ ) and, with borderline significance, the combined outcome BPD at 28 days of life or death (RR $0.95,95 \%$ CI 0.91-1.00, $n=3811$ ) [38]. However, there was no difference in BPD at 36 weeks of postmenstrual age (PMA) (RR 0.99, 95\% CI 0.91-1.09, $n=1896$ ) or combined outcome BPD at 36 weeks PMA or death (RR 0.97, 95\% CI 0.90-1.04), neither in prevention nor treatment trials [38]. There was also no difference in mortality or BPD in a meta-analysis evaluating animal-derived surfactants versus protein-containing synthetic surfactants [39]. Two meta-analyses on RCTs comparing bovine and porcine surfactants showed conflicting results. Singh et al. reported an inferiority of bovine surfactant compared to poractant with increased rates of mortality (RR 1.44, 95\% CI 1.04-2.00, $n=901$ ) and combined BPD or mortality (RR 1.30, 95\% CI 1.04-1.64) [40]. There was no difference in the rates of BPD at 36 weeks PMA (RR $0.94,95 \%$ CI $0.79-1.12, n=899)$. In a subgroup analysis at the initial dose of poractant $(\leq 100 \mathrm{mg} / \mathrm{kg}$ versus $>100 \mathrm{mg} / \mathrm{kg}$ ), these results remained only in the group with the (recommended) higher initial dose of poractant [40]. In contrast, Sánchez-Luna et al. included more recent RCTs and found no difference in mortality (OR $1.35,95 \%$ CI $0.98-1.86$ ) or BPD at 36 weeks PMA (OR 1.25, 95\% CI 0.96-1.62), but no data on the combined outcome BPD or death has been given in this meta-analysis [41]. They also addressed the question about the recommended dosage regimen: Trials with $100 \mathrm{mg} / \mathrm{kg}$ for beractant and poractant showed no differences in BPD or mortality [41-47]. Trials using the recommended dosage of $100 \mathrm{mg} / \mathrm{kg}$ beractant versus $200 \mathrm{mg} / \mathrm{kg}$ poractant for the initial dose, followed by $100 \mathrm{mg} / \mathrm{kg}$ for subsequent doses, showed no difference in mortality (OR $1.39,95 \%$ CI 0.81-2.38) but a borderline significance of BPD at 36 weeks PMA in favor of poractant (OR 1.34, 95\% CI 1.00-1.79) [41].

Not alone, surfactant replacement therapy but, especially, the way of administration and respiratory management around surfactant application have an impact on the development of BPD. The routine application of continuous positive airway pressure (CPAP) and more restrictive use of mechanical ventilation, as described in the section Ventilation Strategies, led to different surfactant administrations. A meta-analysis on INtubationSurfactant-Extubation (INSURE) versus nasal CPAP without surfactant showed only a trend without significance favoring INSURE regarding mortality (RR 0.94, 95\% CI 0.67-1.32), BPD (RR 0.86, 95\% CI, 0.71-1.03) and combined BPD or death (RR $0.88,95 \%$ CI, 0.76-1.02) with a moderate level of evidence [48]. One recent randomized controlled trial extended the INSURE procedure by a recruitment maneuver (REC) with highfrequency oscillation ventilation before surfactant administration (IN-REC-SUR-E) [49]. Compared to INSURE, fewer infants treated with IN-REC-SUR-E needed mechanical ven- 
tilation during the first $72 \mathrm{~h}$ of life; however, there was no difference in the incidence of moderate-to-severe BPD or (per-protocol) mortality [49].

In order to avoid any mechanical ventilation, surfactant administration via a small catheter in spontaneously breathing infants has been established, mostly named as "lessinvasive surfactant administration (LISA)" or "minimally invasive surfactant therapy (MIST)". Consistent results were presented by three meta-analyses favoring LISA/MIST compared to the invasive application of surfactants with a significant reduction in BPD with an OR ranging from 0.47 to 0.72 [50-52] and combined BPD or death (OR ranging from 0.74 to 0.75 ) [50,51]. A network meta-analysis of Isayama et al. found LISA to be the best strategy for noninvasive respiratory management [53]. Compared to a surfactant with continued mechanical ventilation, LISA has a reduced combined rate of BPD or death (OR 0.49, 95\% CI 0.30-0.79 and BPD (OR 0.53, 95\% CI 0.27-0.96), with the quality of evidence graded as moderate [53]. Another more recent network meta-analysis of Bellos et al., including RCTs and observational studies, could show the superiority of LISA/MIST compared to INSURE regarding both the mortality (OR 0.64, 95\% CI 0.54-0.76) and BPD (OR 0.57, 95\% CI 0.44-0.73) [54]. The subgroup analysis of infants born before 28 weeks of gestation did not report on BPD but showed the feasibility and efficacy of LISA/MIST in this particularly vulnerable population, with a reduction in mortality (OR $0.56,95 \% \mathrm{CI}$ $0.46-0.67)$ [54].

\subsection{Caffeine}

Caffeine is a methylxanthine that acts as a nonspecific inhibitor of adenosine receptors. There are four different adenosine receptors, and caffeine inhibits three of them $\left(\mathrm{A}_{1}, \mathrm{~A}_{2 \mathrm{~A}}\right.$ and $A_{2 B}$ ) $[55,56]$. Adenosine is a purine nucleoside that is produced naturally in different human tissues [57]. Caffeine stimulates breathing by various mechanisms. Among others, it has an effect on the diaphragm, minute ventilation and sensitivity to carbon dioxide $\left(\mathrm{CO}_{2}\right)$ sensitivity. It is thanks to the efforts of the Caffeine for Apnea of Prematurity (CAP) Trial Group headed by Barbara Schmidt that we have high-quality and reliable data not only on short-term but also long-term outcomes of caffeine use in extremely preterm infants [58].

CAP was launched to determine whether survival without neurodevelopmental disability at a corrected age of 18 months is improved if apnea of prematurity is managed without caffeine in infants at a high risk of apneic attacks [58]. However, the trial confirmed that caffeine has another clinically important benefit, a reduction in the risk of BPD: 350 out of 963 infants assigned caffeine (36.3\%) received supplemental oxygen at 36 weeks PMA, as compared with 447 out of 954 infants (46.9\%) assigned a placebo (OR $0.63,95 \% \mathrm{CI}$ 0.52-0.76) [58].

The median age of starting study medication in the CAP trial was three days, and the median age of stopping caffeine was 34.4 weeks PMA [58]. Neonatologists asked the question of whether caffeine started earlier than three days, and given longer than 35 weeks, PMA further improves health outcomes. The European consensus guidelines on the management of respiratory distress syndrome recommend that "early caffeine should be considered for babies at high risk of needing mechanical ventilation such as those on non-invasive respiratory support" [59], and this recommendation is supported by various observational studies and systematic reviews [60,61]. Several recent meta-analyses on high versus standard maintenance doses of caffeine came to similar conclusions that high-dose caffeine citrate (10-20 mg/kg per day) might reduce the incidence of BPD, but no general recommendation can be given due to the low quality of evidence [62-65]. The use of therapeutic drug monitoring of caffeine in routine practice could improve its effects on chronic lung disease and avoid the side effects of high doses [66,67]. 


\subsection{Ventilation Strategies}

Mechanical ventilation in animals can induce structural and inflammatory changes that mimic human BPD $[68,69]$. There is a strong link between the use of supplemental oxygen and mechanical ventilation and the incidence of BPD [5]. There are few doubts, that mechanical ventilation, as well as the use of oxygen, are both the risk indicator and risk factor in the pathogenesis of BPD [9]. Therefore, the first and most important advice for mechanical ventilation to prevent BPD is: do not do it [70]. However, a solid number of infants are still unable to survive without mechanical ventilation, and despite a substantial number of RCTs in ventilation strategies, there is uncertainty about how to ventilate in the least harmful manner [71].

Cochrane reviews cover the topics of synchronization [72], elective high-frequency oscillation (HFO) [73], high-frequency jet ventilation (HFJV) [74,75], volume-targeted ventilation [76], positive end-expiratory pressure (PEEP) application [77], inspiratory times [78], permissive hypercapnia [79], neurally adjusted ventilatory assist [80] and the type of trigger that is used for synchronization [81].

\subsubsection{High-Frequency Ventilation}

High-frequency ventilation therapy is using much smaller tidal volumes than conventional ventilation. Considering volutrauma as a major contributing factor to ventilatorinduced lung injury, minimizing tidal volumes is a promising strategy. A Cochrane review summarized the results of 19 RCTs on elective high-frequency oscillation ventilation (HFOV). The combined outcome death or BPD at 36 weeks PMA was reduced with HFOV (RR 0.90, 95\% CI 0.84-0.97, $n=3329$ ), resulting mainly from a reduction in BPD (RR $0.86,95 \%$ CI $0.78-0.96, n=2786$ ) but with significant heterogeneity between studies. However, using a random-effects model, the reduction of BPD and BPD or death remained significant [73]. The meta-analysis showed an increased incidence of pulmonary air leak (RR 1.19, 95\% CI 1.05-1.34), likely due to higher mean airway pressures applied during HFOV [73].

As a consequence of the previous version of this Cochrane review [82], which was criticized because of the heterogeneity of the patient characteristics, ventilators and ventilation strategies used, the authors conducted a patient meta-analysis including 3329 participants from 10 RCTs for which individual patient data were available [83]. The risk of death or BPD at 36 weeks PMA with HFOV was 0.95 (95\% CI 0.88-1.03). No subgroup of infants, ventilator type or strategy could be linked to a stronger treatment effect. However, only one of these 10 RCTs used a volume-targeted ventilation mode in the conventional treatment arm. Modern respirators have substantially improved regarding synchronization and tidal volume measurements; therefore, there is a need for RCTs comparing volume-targeted ventilation modes and HFOV [84].

Evidence of high-frequency jet ventilation (HFJV) in very preterm infants is very scarce. A Cochrane review comparing HFOV with HFJV was empty, and a meta-analysis for HFJV versus conventional found only one RCT conducted in the 1980s [85]; therefore, the routine application of HFJV cannot be recommended.

\subsubsection{Volume-Targeted Ventilation}

Ventilator-induced injury happens mainly in the high-volume injury zone (overinflation, volutrauma) and low-volume injury zone (collapse, atelectotrauma). Animal studies showed that even a few overinflations can cause relevant lung injury [68] and high tidal volumes (volutrauma) are more dangerous than high pressures (barotrauma) [86]. A volume-controlled ventilation uses a constant flow, resulting in a steadily rising (and potentially very high) pressure until the set volume is administered, and the peak pressure is only achieved at the very end of the inspiration. Volume-targeted ventilation (VTV) differs substantially from volume-controlled ventilation and combines control over the pressure and tidal volume. Software algorithms adapt the applied pressure (to a set maximum peak pressure) to the exhaled tidal volumes of the last couple of inflations in order to achieve an 
expiratory tidal volume matching the set volume as closely as possible [87]. Targeted tidal volumes are usually set to $4-6 \mathrm{~mL} / \mathrm{kg}$ in conventional ventilation [87] and 1 to $2 \mathrm{~mL} / \mathrm{kg}$ for HFOV [88].

A meta-analysis of the most recent Cochrane review covered 20 RCTs with 977 infants in 16 parallel group trials, resulting in a reduction of BPD at 36 weeks (RR $0.68,95 \% \mathrm{CI}$ $0.53-0.88, n=620$ ) and BPD or death (RR $0.73,95 \%$ CI 0.59-0.89, $n=584$ ) [76]. A subgroupanalysis of extremely low birthweight (ELBW) infants did not show significant results regarding BPD (RR 0.81, 95\% CI 0.59-1.12, $n=202$ ) and combined BPD or death (RR 0.79, $95 \%$ CI $0.62-1.01, n=224$ ) [76]. No adverse outcomes were associated with VTV. In contrast, the meta-analysis showed the benefits of VTV in a shorter mechanical ventilation, lower pneumothorax rate, lower rates of intracranial abnormalities and less hypocarbic episodes. An earlier meta-analysis including 18 RCTs came to a very similar result [89]. Since then, a small RCT has been published in Chinese that reports improved short-term outcomes with volume-guarantee ventilation in the weaning phase but no impact on BPD [90].

\subsubsection{Permissive Hypercapnia}

Reducing the parameters of mechanical ventilation in order to allow arterial $\mathrm{pCO}_{2}$ to rise above $45 \mathrm{mmHg}$ is considered "permissive hypercapnia". The idea behind permissive hypercapnia is, if it is not avoidable, at least to decrease the intensity of mechanical ventilation and to measure the decreased intensity not by the method used but by its effect: a decreased elimination of $\mathrm{CO}_{2}$ [91]. However, sudden changes in $\mathrm{pCO}_{2}$ should be avoided, as it rapidly alters the cerebral blood flow and increases the risk for cerebral hemorrhage [92]. To gain an adequate magnitude of ventilator adjustment, the protocol of the "Permissive hypercapnia in extremely low birthweight infants" (PHELBI) trial suggested a pragmatic approach by changing the settings by the same relative magnitude as the $\mathrm{PaCO}_{2}$ deviation from the target value (e.g., actual $\mathrm{PaCO}_{2} 40 \mathrm{mmHg}$ and target $\mathrm{PaCO}_{2}>50 \mathrm{mmHg}=20 \%$ off-target $\rightarrow$ adjustment: a decreased positive inspiratory pressure (PIP) by 20\%) [93].

A Cochrane review included two RCTs, of which one RCT was very small and the other RCT achieved only a 4-mmHg difference between treatment arms [79]. There was no significant difference for death or BPD at 36 weeks PMA, nor for any other relevant outcome. This review has not been updated since 2001. One subsequent RCT randomized infants between 23 and 28 weeks to either normocapnia $(35-45 \mathrm{mmHg}$ ) or hypercapnia (55-65 mmHg) but was terminated early for failure to achieve the desired $\mathrm{CO}_{2}$ difference in the treatment arms. There were no significant differences in BPD at 36 weeks PMA or combined BPD or death but an increase in death or mental impairment in the hypercapnia group (secondary outcome) [94]. The largest RCT (PHELBI trial) was also terminated early because of very slow recruitment and a lack of funding for further extension [93]. Three hundred and fifty-nine infants between 23 and 29 weeks were randomized within the first day of life. Both arms had $\mathrm{pCO}_{2}$ targets that were rising on day 4 and day 7 by $5 \mathrm{mmHg}$, ending in $50-60 \mathrm{mmHg}$ in the low versus $65-75 \mathrm{mmHg}$ in the high $\mathrm{pCO}_{2}$ arm. Therefore, in fact, both groups targeted the hypercapnic $\mathrm{pCO}_{2}$ levels. Although this study was able to achieve the preset $\mathrm{pCO}_{2}$ levels between treatment arms, there was no difference in the primary outcome death or BPD at 36 weeks. However, no adverse effect of hypercapnia on the neurodevelopmental outcome was reported [95].

\subsubsection{Supplemental Oxygen}

Exposure to oxygen has been associated with BPD. Infants $<30$ weeks randomized to $\mathrm{SpO}_{2}$ target $95-98 \%$ have a higher risk of requiring supplemental oxygen at 36 weeks than infants randomized to $92-94 \%$ (OR 1.40, 95\% CI 1.15-1.70) [96]. A meta-analysis of the subsequent RCTs demonstrated a lower rate of supplemental oxygen in infants randomized to a $\mathrm{SpO}_{2}$ target of $85-89 \%$ as opposed to $91-95 \%$ (RR $0.81,95 \%$ CI $\left.0.74-0.90\right)$, but this was counteracted by an increased risk of death and necrotizing enterocolitis (NEC) [97]. More recently, ventilators have been equipped with pulse oximetry and algorithms to adapt 
the inspired fraction of oxygen to the set $\mathrm{SpO}_{2}$ target. It has been established that these algorithms are able to increase the time spent within the target range and reduce the time at hypoxia and hyperoxia [98]. However, it is unclear whether these improvements translate into a reduction of BPD or other patient-relevant outcomes.

\subsubsection{Synchronization}

Synchronization, either by higher respiratory rates $(60-80 / \mathrm{min})$ as compared to lower rates (30-40/min) or by different triggered ventilation modes, has advantages on the incidence of air leaks but has no established effect on BPD at 36 weeks [72]. The same applies for a meta-analysis of RCTs comparing long with short inspiratory times-there was an advantage for a short inspiration time and higher frequency in terms of air leaks but not in terms of BPD [78]. A Cochrane review [80] identified one RCT on NAVA versus pressure-controlled ventilation, which found no difference in the rates of BPD or other relevant outcomes [99].

\subsubsection{Early Extubation}

If intubation and mechanical ventilation was either necessary as a life-saving procedure or deemed the least harmful strategy of respiratory support in a particular situation, it does not mean that it needs to be continued until successful extubation can be safely predicted. Preterm infants probably benefit from early extubation [100], even if no preextubation test can predict if reintubation will be necessary or not [101-103]. Extubation to noninvasive ventilation and caffeine will increase the chances of success, while corticosteroids should be used judiciously [104].

\subsubsection{Tracheostomy Placement}

Ongoing intensive respiratory support, e.g., mechanical ventilation or high-level noninvasive respiratory support, in infants with established severe BPD at around termequivalent age prompts the question for further respiratory management. Retrospective cross-sectional studies have shown an increased placement of tracheostomy in very preterm infants in US hospitals over the last decades [105,106], while data from the Neonatal Research Network of Japan have shown a steady rate of interventions [107]. The evidence on tracheostomy is based on retrospective cohorts or case-control studies only. DeMauro et al. evaluated the outcome of infants born before 30 weeks of gestation surviving to a PMA of 36 weeks $(n=8683)$ [108]. Those with tracheostomy $(n=304)$ compared to those without had a higher risk for the composite outcome of death or neurodevelopmental impairment (adjusted OR 3.3, 95\% CI 2.4-4.6) but with a lower mortality rate (OR 0.4, 95\% CI 0.3-0.7). The authors of the study interpreted the results more likely to be a noncausal association of tracheostomy and neurodevelopmental impairment in these infants [108]. The study also analyzed the impact of timing of tracheostomy on the composite outcome, favoring earlier tracheostomy before 120 days of life in contrast to later tracheostomy (OR 0.5, 95\% CI 0.3-0.9). A small single center study included 72 infants born before 32 weeks of gestation or birth weight $<1500 \mathrm{~g}$ receiving tracheostomy due to severe BPD (median 51.8 weeks PMA, median 183 days of life) analyzing the growth parameters and participation in developmental therapy four weeks before tracheostomy placement and a four-week period after [109]. Infants showed a significantly higher weekly gain of weight, length and head circumference after tracheostomy despite a lower caloric intake. Additionally, after tracheostomy placement, infants had a lower daily sedation requirement and participated more often in developmental therapies, with a shift of focus from activities promoting physiologic stability to activities promoting developmental skill acquisition [109]. 
Longitudinal studies on the five-year survival rates and decannulation rates of infants with tracheostomy due to ventilator-dependent BPD show a post-discharge survival of $73-81 \%$ and a five-year decannulation rate ranging between $0 \%$ to $97 \%$, depending especially on neurological comorbidities [110-112]. The median age at decannulation was 32 to 38 months in the cited studies [110-112].

\subsection{Postnatal Corticosteroids}

Inflammation, e.g., due to ventilator-induced lung injury, oxygen toxicity or infection, contributes mainly to the development of BPD; therefore, the use of corticosteroids (CS) with a potent anti-inflammatory effect is deemed reasonable. The very widespread use during the 1980s resulted in increasing rates of adverse neurodevelopmental outcome (NDO), especially cerebral palsy. That resulted in an almost complete cessation of postnatal corticosteroid treatment. A (meanwhile updated) meta-regression of Doyle et al. showed the necessity of risk-benefit assessment, as infants with very high risk might profit from CS treatment, even regarding the NDO [113]. Two Cochrane reviews exist that evaluated early ( $\leq$ seven days) and late (>seven days) CS for the prevention of BPD with a moderateto-high quality of evidence that both resulted in a reduction of BPD and BPD or death and prevented extubation failure. The relevant side effects included an elevated risk for intestinal perforation, gastrointestinal bleeding, risk of infections, hyperglycemia, hypertension and hypertrophic cardiomyopathy; therefore, the authors concluded that the benefits may not outweigh the adverse effects [114,115]. To reduce BPD, the most efficient CS is dexamethasone, especially in a high-dose regimen (OR 0.29,95\% confidence interval $0.14-0.52, n=659$ ) analyzed by a network meta-analysis but also has the highest risk for cerebral paresis (OR 2.02, 95\% confidence interval 0.60-4.67, $n=307$ ) [116]. Hydrocortisone might have fewer side effects, especially regarding NDO. A recent individual patient data meta-analysis examined the use of low-dose hydrocortisone as a prophylaxis for early adrenal insufficiency for 10 to 15 days. Treated infants had a higher rate of survival without BPD (OR 1.45, 95\% CI, 1.11-1.90, $n=979$ ) and a reduction of BPD (OR 0.73, $95 \%$ CI $0.54-0.98, n=802$ ) without a difference in death or impaired NDO [117]. However, the latest SToP-BPD RCT randomized 372 infants in a 22-day course of hydrocortisone or placebo and failed to show an effect on the BPD or death at 36 weeks PMA [118], and long-term data are not yet available.

To avoid systemic side effects, topic treatment with CS intratracheal instillation with surfactant as the vehicle and inhaled CS have been used. The meta-analysis of two trials of intratracheal instillation CS show a reduction of BPD (RR 0.19,95\% CI 0.10-0.28, $n=381$ ) and the combined outcome of BPD or death (RR 0.26, 95\% CI 0.16-0.35, $n=381$ ) [119]; yet, data on long-term outcomes are not yet published, and further trials are underway. A meta-analysis of 16 RCTs showed that the inhalation of CS not only reduced the used amount of systemic CS but also led to a reduction of BPD (RR $=0.77,95 \%$ CI 0.65-0.91, $n=1168$ ) and BPD or death (RR 0.86, 95\% CI 0.75-0.99, $n=1285$ ) [120]. No significant change in mortality (RR $0.97,95 \%$ CI $0.42-2.2, n=1270$ ) could be detected. This is of importance, as the mortality rate of the major contributing NEurOSIS study $(n=863)$ was (nonsignificant, but nonetheless) elevated (1.24; 95\% CI, 0.91-1.69) [121]. A long-term follow-up of this study showed no difference in NDO but still an increased mortality rate in the budesonide group (RR 1.37, 95\% CI, 1.01-1.86) [122]. The authors of NEurOSIS did not find a plausible explanation for the elevated mortality. A meta-analysis of Zheng et al. on long-term effects of the intratracheal administration of CS, including five trials $(n=1515)$, did not find a significant difference in the mortality (RR 1.13, 95 CI 0.90-1.41, $n=1465$ ) but, also, neither in the benefits regarding NDO nor adverse effects [123]. 


\subsection{Inhaled Nitric Oxide (iNO)}

For the purpose of this review, only the prophylactic use of iNO to prevent BPD will be examined.

Endogenous NO is required for alveolar and vascular development [124]. Recent data suggest that there is a relevant vascular component in the development of BPD [125]. There is an association between disturbed NO signaling in BPD; however, it is controversial whether this causal for resulting from developing pulmonary damage or both [126].

In 2011, the results of an NIH Consensus Development Conference and of an individual patient-data meta-analysis have been published. Both concluded that, despite the sound and plausible pathophysiologic basis, there was no benefit nor harm from prophylactic treatment of preterm infants with iNO $[127,128]$. At that time, it remained unanswered if a particular subgroup of infants might benefit from iNO or if there were treatment-relevant (timing, dose and duration) variables that might explain the gap between basic research and clinical trials. Data from 12 RCTs were analyzed and yielded in a RR of 0.96 (95\% CI $0.92-1.01, n=3298$ ) for the primary combined outcome of death (RR 1.05, 95\% CI 0.93-1.18) or BPD at 36 weeks PMA (RR $0.93,95 \%$ CI 0.87-1.00). Subgroup analyses indicated a possible benefit for black infants and for trials with starting dosage $>5 \mathrm{ppm}$ [127]. Another meta-analysis, on which the NIH Consensus Statement was based, found a borderline significant effect from 14 RCTs for the combined outcome of death or BPD (RR $0.93,95 \%$ CI $0.86-0.99, n=3129)[129,130]$.

The most recent Cochrane Review included data from 17 RCTs, including three new RCTs since 2011 [131]. Due to significant heterogeneity in the inclusion criteria, they did not perform an overall analysis but divided the trials into three groups: eight trials of early rescue treatment based on oxygenation, four trials examining early routine use of iNO in infants with pulmonary disease and three trials with later start of treatment ( $>3$ days) based on risk of BPD. Risk of death or BPD was similar in all three group of trials (early rescue: RR $0.94,95 \%$ CI $0.87-1.01, n=958$; early prophylactic: RR $0.94,95 \%$ CI $0.87-1.02, n=1924$ and late: RR $0.92,95 \%$ CI 0.85-1.01, $n=1075)$. A nonsignificant increase of severe intraventricular hemorrhage was found only in the early rescue group (RR 1.20, 95\% CI 0.98-1.47, $n=773$ ), potentially reflecting a side effect due to the inhibition of platelet aggregation by iNO. One additional RCT, including 451 infants born $<30$ weeks of gestation, has been published. There was no difference in survival without BPD at 36 weeks (OR 1.17, 95\% CI 0.79-1.73) or BPD severity or IVH [132].

To answer the question whether iNO might be beneficial for infants of African American descent treated with doses $>5 \mathrm{ppm}$ and for $>$ seven days, an individual patient data meta-analysis from three RCTs was carried out [133]. It demonstrated a reduced risk for death or BPD (RR 0.77, 95\% CI 0.65-0.91) and for BPD alone (RR 0.75, 95\% CI 0.61-0.91), no effect at all for White, non-Hispanic and an intermediate nonsignificant effect for Hispanic infants [133].

\subsection{Inhaled Bronchodilators}

Inhaled bronchodilators include nonspecific beta-adrenergic agents, such as isoproterenol, and specific beta-adrenergic agents, such as albuterol, metaproterenol, terbutaline and isoetharine or inhaled anticholinergic agents as atropine or ipratropium. The use of bronchodilators in BPD has been justified by their potential effect of dilating small airways that have muscular hypertrophy. Furthermore, BPD is associated with an increased airway resistance, decreased dynamic compliance and wheezing. If bronchodilators were administered in short-term studies of pulmonary mechanics in infants with BPD, an increased compliance, as well as decreased pulmonary resistance, have been documented [134-136]. However, data on clinically relevant outcomes are sparse. 
The most recently updated systematic review from the Cochrane Collaboration included only two small studies that reported on 225 infants [137]. One study included 73 infants but reported on 52 infants and examined the prevention of BPD with the use of aminophylline [138]. Methodological quality was reported to be very low according to the GRADE classification system. The use of prophylactic aminophylline was associated with a reduction in BPD at 28 days of life (RR 0.18,95\% CI 0.04-0.74) and a shorter duration of supplementary oxygen therapy. There was no difference in mortality (RR 3.0, 95\% CI 0.33-26.99). The second study included in the Cochrane review enrolled 173 infants to look at the prevention of BPD with the use of salbutamol [139]. According to GRADE, the quality of the evidence was moderate. Infants treated with inhaled prophylactic salbutamol compared to controls showed no differences in mortality (RR 1.08, 95\% CI 0.50-2.31) nor in BPD (RR 1.03, 95\% CI 0.78-1.37) or other complications associated with preterm birth. The study did not report on side effects due to salbutamol. The authors of the systematic review from the Cochrane Collaboration found no eligible trial that studied the use of bronchodilator therapy for the treatment of individuals with BPD [137]. Another systematic review used less strict inclusion criteria and included five further small RCTs $(n=84)$ on beta-agonists [140]. However, due to substantial heterogeneity, no meta-analysis could be performed, and the included studies did only report on short-term measurements with improvement of compliance and resistance but not on clinically relevant outcomes such as BPD or mortality [140]. Despite missing evidence, a recent retrospective multicenter cohort study including 4986 preterm infants born before 32 weeks of gestation with developing BPD at 28 days of life showed the widespread use of inhaled bronchodilators in US hospitals [141]. Twenty-five percent (1224/4986) received at least one dose of inhaled bronchodilators between 28 days of life and discharge or death and, those developing severe BPD at 36 weeks PMA, even 48\% (664/1390).

\subsection{Macrolides}

Ureaplasma spp. are amongst the most common microbes isolated from maternal samples, as well as neonatal tracheal aspirates [142], and they might cause a chronic pulmonary inflammation contributing to the development of BPD [143-145] — in particular, in ventilated infants [146]. A meta-analysis quantified the OR for BPD at 36 weeks to 2.22 (95\% CI 1.42-3.47) for Ureaplasma-positive infants [147]. Macrolides have a role in pediatric chronic inflammatory pulmonary conditions like cystic fibrosis, so they also might work to prevent BPD, either by an intrinsic anti-inflammatory effect or by affecting colonization status with pathogenic bacteria [148].

Erythromycin was evaluated by two small RCTs, which are summarized but not combined in a meta-analysis in the relevant Cochrane review [149]. Both were randomized infants $<30$ weeks, one with unknown and one with positive colonization status. Neither showed a significant difference between Erythromycin and no therapy with regard to death, BPD or the combined. A later meta-analysis evaluated all RCTs on Erythromycin, Clarithromycin and Azithromycin [150]. They found a borderline nonsignificant effect of prophylactic macrolides on the combined death or BPD at 36 weeks (RR 0.89, 95\% CI 0.79-1.01, $n=438$ ) and a stronger but wider effect in Ureaplasma-positive infants only (RR $0.41,95 \%$ CI $0.05-3.13, n=150$ ), with only two studies having a satisfying quality. A subgroup analysis on prophylactic Azithromycin only could show a reduction of BPD (RR $0.83,95 \%$ CI $0.71-0.97, n=310$ ) and combined outcome of BPD or death (RR $0.86,95 \%$ CI $0.77-0.97, n=363$ ) [150]. However, the most recent meta-analysis for Azithromycin including five RCTs with 564 moderate to extremely preterm infants found no difference in BPD, mortality or the combined outcome BPD or death despite the lower duration of supplemental oxygen [151].

The protocol of the AZTEC trial was published recently [152]; it will randomize 796 infants $<30$ weeks to a 10-day course of azithromycin. The trial will also investigate the incidence of NEC and of resistance to Azithromycin in stool samples, but it will not be powered to detect the impact of shifts in the microbiome and antimicrobial patterns. 


\subsection{Microbiome and Antibiotic Treatment}

The complex interaction of microbiome of intestines and lungs with the developing immune system and organ development will likely provide further insight in the development of BPD [153]. Microbial dysbiosis may be associated with BPD progression and severity [145]. A prolonged antibiotic treatment in infants without culture-positive sepsis and negative inflammatory parameters might lead to such microbial dysbiosis. Higher rates of antibiotic use in culture-negative sepsis were associated with adverse neonatal outcomes, including the development of BPD [154]. However, the risk/benefit ratio of antibiotic use regarding the higher incidence of early- and late-onset sepsis in VLBW and ELBW infants remains challenging; therefore, the implementation of antibiotic stewardship to avoid unnecessary antibiotic treatment is recommended [155].

\subsection{Patent Ductus Arteriosus}

A patent ductus arteriosus (PDA) is a very common morbidity in preterm infants. In extremely preterm infants $\leq 28$ weeks of gestation, an incidence of hemodynamically significant PDA of $57 \%$ has been reported after the first week with an inverse correlation to gestational age, reaching a maximum of $93 \%$ in infants of 23-24 weeks of gestation [156]. The effect of an existing PDA on mortality and morbidities and the resulting urge to treat a PDA are still a matter of debate $[157,158]$. A meta-analysis of observational studies found major morbidities as intraventricular hemorrhage (IVH), necrotizing enterocolitis (NEC) and BPD related with PDA [159]. These results have to be interpreted with caution, as this association is not necessarily a causality. A meta-analysis of placebo-controlled RCTs could not show any difference in mortality, IVH, NEC or BPD [160]. However, with a median $52 \%$ rate of rescue treatment in the control groups, the investigators of the metaanalysis questioned the evidence for good reason [160]. Most RCTs aim at the efficacy to close the PDA and may be underpowered to estimate the impact on neonatal mortality or major morbidities [158]. Therefore, all Cochrane meta-analyses on the different pharmacological treatment options (indomethacin, ibuprofen or paracetamol (acetaminophen) targeting cyclooxygenase-I) failed to show an effect on mortality or BPD despite being effective in PDA closure [161-165]. A recent network meta-analysis evaluated RCTs regarding the different pharmacological interventions (indomethacin, ibuprofen, paracetamol (acetaminophen) or placebo) and found no difference in mortality or morbidities even compared to the placebo but higher rates of side effects as oliguria, especially in indomethacin and ibuprofen [166]. The same conclusion was drawn in another network meta-analysis on RCTs and observational studies [167].

The rates of surgical ligation of the PDA decreased substantially in a US cohort of 61,520 preterm infants born between 23 and 30 weeks of gestation from $8.4 \%$ in 2006 to $2.9 \%$ in 2015 [168]. A meta-analysis of one RCT and 39 cohort studies evaluating surgical ligation showed a reduced mortality (pooled adjusted OR (aOR) 0.54, 95\% CI 0.38-0.77, $n=7159$ ), but an increase in morbidities such as BPD (pooled aOR 2.51, 95\% CI 1.98-3.18, $n=6703$ ) and higher rates of impaired neurodevelopmental outcome (aOR 1.54, 95\% CI 1.01-2.33) [169]. The potential survival bias was addressed in a retrospective cohort study including 754 infants adjusting not only for pre- and perinatal confounding factors but, also, for postnatal factors representing the severity of illness [170]. There was still a reduction in mortality (aOR $0.09,95 \%$ CI $0.04-0.21$ ) but no more difference in BPD or the neurodevelopmental outcome [170]. Despite these results, the substantial rates of procedural complications up $44 \%$, including post-ligation cardiac syndrome, vocal cord paralysis and acute kidney injury, have to be taken into account [157].

Percutaneous catheter intervention to close the PDA is associated with high rates of adverse events $(23 \%)$ and clinically significant adverse events $(10 \%)$ in a meta-analysis of observational studies on infants of $<$ one year [171]. A newer device has been approved for interventional closure of the PDA in preterm infants $\geq 700 \mathrm{~g}$ with promising first results [172], but further studies are necessary before a routine use can be recommended. 
During the last decade, the clinical management of PDA shifted significantly from an active treatment towards "watchful waiting", as most PDAs close spontaneously, and all interventions, pharmacological and surgical, have potential adverse effects [156,157,167,173]. A recent Cochrane meta-analysis (14 trials, $n=910$ infants) found no difference in mortality or BPD comparing early treatment before 7 days of life versus expectant management or very early treatment before $72 \mathrm{~h}$ of life and versus expectant management [174].

Watchful waiting should not be interpreted as doing nothing: During "waiting", increased positive airway pressure should be applied, and volume overload due to liberal fluid management should be avoided [175,176] (see section Fluid Management). "Watchful" means regular clinical and echocardiographic reevaluation of the PDA as recent RCTs suggest that not a binary variable "PDA existent or not" but the magnitude of PDA shunt affects the outcome [177]. Exposure to a moderate to large PDA of seven to 13 days led to an increase of the combined outcome of BPD or death (OR 2.12,95\% CI 1.04-4.32). An exposure of $\geq 14$ days further increased the risk of BPD or death (OR 3.86, 95\% CI 2.15-6.96) and BPD alone (OR 4.09, 95\% CI 2.32-7.22) [177].

\subsection{Fluid Management and Nutrition}

The definition of restrictive or liberal fluid intake varies widely. Sung et al. proposed a very restrictive approach with $60 \mathrm{~mL} / \mathrm{kg}$ on the first day of life to $<116 \mathrm{~mL} / \mathrm{kg} /$ day during the first weeks [175]. Other studies defined low intake as $<96 \mathrm{~mL} / \mathrm{kg}$ on the first day of life proceeding to $<135 \mathrm{~mL} / \mathrm{kg} / \mathrm{d}$ after the first week [178]. The latter is comparable to the studies included in the Cochrane review of Bell and Acarregui [179] but exceeded that by Letshwiti et al. (mild fluid restriction 130-150 mL/kg/d) [176] or the applied cut-off value of $<150 \mathrm{~mL} / \mathrm{kg} / \mathrm{d}$ in the Cochrane review of Barrington et al. [180].

The meta-analysis of early fluid management showed a reduction of hemodynamically significant PDA and NEC with a restrictive water intake, but the impact on BPD (RR $0.85,95 \%$ CI $0.63-1.14$ ) or mortality (RR $0.81,95 \%$ CI $0.54-1.23$ ) was not significant [179]. Comparable results were presented by a cohort study with an increased risk for PDA with higher fluid intake, but the association with BPD in univariate analysis remained no longer significant in regression analysis [178]. However, a retrospective secondary analysis of a RCT cohort could show the association of BPD or death with a high fluid intake and lower weight loss during the first 10 days of life [181] similar to other cohort studies [182-184].

Evidence on a restrictive fluid management to treat BPD is even scarcer. A Cochrane meta-analysis found insufficient data on that subject [180], with the only included study not reporting on mortality or BPD at 36 weeks PMA. The idea of reducing pulmonary edema with a resulting improvement of pulmonary function and gas exchange due to shorter diffusion distance is the rational for the widespread use of diuretics in neonatology [180, 185,186]. Meta-analyses of RCTs evaluating loop diuretics as furosemide or diuretics acting on the distal tubule (thiazide and spironolactone) showed improvement in pulmonary mechanics but did not report on BPD [187-189]. Only two included small trials on chronic administration of thiazide-spironolactone showed a decreased mortality rate (RR 0.30, 95\% CI $0.09-0.93 ; n=77$ ) [189]. A recent cohort study analyzed the mortality rates of infants with moderate to severe BPD in 43 US children's hospitals. There was no difference in mortality comparing hospitals with "low" and "high" cumulative loop diuretic use [186]. Greenberg et al. examined a large cohort including 37,693 infants born before 29 weeks of gestation comparing exposure to furosemide to no exposure in regards of BPD and combined BPD or death [190]. The binary variable "exposure" yes or no was not significant, but the percentage of exposure days between the seventh day of life to 36 weeks PMA showed a reduction of BPD and of BPD or death. They could show an increase in furosemide exposure days of 10 percentage points, leading to 4.6-percentage point decrease in BPD $(p=0.001)$ and a 3.7-percentage point decrease in BPD or death $(p=0.01)$ [190]. On the other hand, a prolonged diuretic treatment with furosemide is associated with relevant side effects as electrolyte imbalances, nephrocalcinosis and ototoxicity [191]. 
As energy expenditure is higher in infants with BPD due to a higher respiratory rate and breathing work [192] and the association of postnatal growth failure with BPD development [193], early calorie intake likely has an important effect on BPD development. As a meta-analysis could not find any RCT evaluating standard versus high-energy intake [194], evidence for the association of BPD and lower calorie intake is based on cohort studies $[184,193,195]$. Especially delayed or prolonged time to full enteral feeding was associated with BPD development $[183,184,193,195,196]$, but this may be a confounding factor, as immaturity or more critical condition led to feeding intolerance. A calorie/protein ratio below that recommended for growth was found in preterm newborns who developed $\mathrm{BPD}$, and providing nutrition for these newborns remains a challenge [195]

Human milk is known to be protective against NEC [197] and seems to have a protective effect on BPD development as well. Recent meta-analyses of RCTs and observational studies found a reduction of BPD in infants fed with human milk compared to preterm formula (RR 0.78, 95\% CI 0.67-0.90) [198,199]. This effect was no longer significant when only RCTs were evaluated. Another meta-analysis focused on maternal breast milk and showed a reduction of BPD in exclusively maternal breast milk-fed infants (RR 0.74, 95\% CI 0.57-0.96), but as other feeding dosages with maternal breast milk showed no effect, the investigators suggested caution with the interpretation of the results [200]. Still, human milk provides various protective mechanisms, including specific nutrients and factors. However, the protein concentration may vary widely in human milk, and the fortification of human milk to prevent extrauterine growth failure is essential [201]. Standardized fortification with a fixed amount of fortifier per $100 \mathrm{~mL}$ of human milk is still the most applied method in NICUs. Individualized fortification, which is adjustable fortification (by measuring the infant's blood urea nitrogen) or targeted fortification (measuring the macronutrient content of human milk), seems to be superior compared to standardized fortification regarding the gain of growth parameters in a recent Cochrane meta-analysis, but the included seven studies did not present data on the development of BPD or long-term outcomes [202]. Last, human milk has an important influence on the immature microbiome, which is an important focus of very recent research [153].

\subsection{Vitamin $A$}

Vitamin A supplementation is one of the prevention strategies that has stood the test of time [203] from old to new BPD, from the first RCT in 1987 [204] until the latest metaanalysis in 2021 [205]. During the fetal period, vitamin A is crucial for respiratory epithelial cells, cellular differentiation and surfactant production and vitamin A levels were found to be lower in subjects developing BPD [206], prompting the idea, that supplementation might reduce incidence or severity of BPD.

A Cochrane review showed a small risk reduction of death or oxygen requirement at 28 days of life (RR $0.93,95 \%$ CI $0.88-0.99$ ) and of BPD at 36 weeks PMA (RR 0.87, 95\% CI $0.77-0.99, n=986)$. However, including mortality as a combined outcome at 36 weeks PMA yields in loss of significance (RR 0.92, 95\% CI 0.84-1.01) [207]. A meta-analysis on infants with a birth weight $<1000 \mathrm{~g}$ (ELBW) only found a decrease in BPD at 36 weeks PMA (RR $0.88,95 \%$ CI $0.77-0.99, n=1011$ ) without an effect on mortality or oxygen use at 28 days of life [208], comparable to a more recent but smaller meta-analysis of only two RCTs [209]. Ding et al. showed in the most recent meta-analysis a reduced incidence of BPD at 36 weeks PMA (OR $0.67,95 \%$ CI $0.52-0.88$ ) without a difference in mortality or other morbidities [205]. However, the effect might not be big enough to justify repeated painful intramuscular injections, and it has also been questioned, whether under the circumstances of current neonatal intensive care standard therapies, the supplementation with vitamin A is still essential [210]. Two very recent RCTs analyzed enterally administered vitamin A at $5000 \mathrm{IU}$ per day [211] or 10,000 IU every other day [212] and found higher plasma retinol levels in the same range of previous non-enteral studies [213]. Despite that, the Australian study found no difference in BPD or mortality in the 188 included infants born $<28$ weeks of gestation likely to the low baseline incidence of BPD in their cohort [211]. The Indian 
study of Basu et al. examined 196 VLBW infants and found a reduction of the composite outcome death or oxygen requirement at 28 days of life (RR $0.44,95 \%$ CI $0.23-0.84$ ) and a nonsignificant reduction of BPD at 36 weeks PMA (RR 0.22, 95\% CI 0.05-1.00) [212]. A lower dose of oral vitamin A of 1500 IU per day was administered to infants born $<28$ weeks of gestation in a RCT for the prevention of retinopathy of prematurity (ROP) and resulted in a reduction of BPD (RR 0.56, 95\% CI 0.37-0.86, $n=262$ ) [214]. Two further trials are waiting for completion [215] or full publication [216]; it is to be expected that, in particular, the NeoVitaA-Trial [217] will add substantial information to the question whether there is a place for high-dose vitamin A under the circumstances of current high-standard neonatal intensive care.

\subsection{BPD Associated Late Pulmonary Hypertension}

A dysregulated angiogenesis during BPD development results in smaller pulmonary arteries and reduced capillary density. This can lead to increased pulmonary vascular resistance, followed by remodeling of the pulmonary arteries [218]. Therefore, infants with $\mathrm{BPD}$ are at high risk to develop pulmonary hypertension (PH). A recent meta-analysis calculated an overall prevalence of $\mathrm{PH}$ of $20 \%$ in preterm infants, with a distribution of $2 \%$ in the absence of BPD, $6 \%$ for mild BPD, $12 \%$ for moderate BPD and $39 \%$ for severe BPD [219], comparable to the results of an earlier meta-analysis [220]. Both studies reported on an around five-fold higher mortality of infants with BPD and PH compared to BPD alone. Furthermore, $\mathrm{PH}$ was associated with more frequent readmissions and a high postdischarge mortality [221-223]. In surviving infants, BPD-associated PH resolved in the majority of cases during the first two years of life [222,223]. PH is not uniformly defined in neonates and is usually estimated via echocardiography. Right ventricular systolic pressures (RVSP) $>40 \mathrm{mmHg}$ measured via tricuspid regurgitation jet velocity (plus an estimated $5 \mathrm{mmHg}$ of right atrial pressure), a RVSP/systemic systolic blood pressure ratio $>0.5$, a systolic flattening of the interventricular septum or right-to-left or bidirectional cardiac shunt or PDA are the most common noninvasively obtained parameters $[223,224]$. The management of BPD therefore has to include an echocardiographic screening for PH, as suggested by the consensus guidelines of the European Pediatric Pulmonary Vascular Disease Network (EPPVDN) [225,226]. At least at diagnosis of BPD with 36 weeks PMA, an echocardiography should be performed to assess a possible PH [225-227]; other algorithms recommend serial examinations from the seventh day of life for an earlier diagnosis of $\mathrm{PH}$ [218]. Infants with signs of PH in a predischarge echocardiography should be referred to an outpatient cardiologic follow-up [227].

Treatment options include oxygen therapy, diuretics and pulmonary vasodilators [225]. The question of the "right" targeted $\mathrm{SpO}_{2}$ level in neonatal care has been the objective of many studies. A recent retrospective cohort study found a reduced incidence of $\mathrm{PH}$ with a higher targeted $\mathrm{SpO}_{2}$ of 90-95\% [228]. The recommendation of EPPVDN even exceeds this threshold in infants with established $\mathrm{PH}$, suggesting an oxygen saturation $\geq 93 \%$ in suspected and even $\geq 95 \%$ in proven $\mathrm{PH}$ [225]. At least there is robust evidence to avoid pulmonary vasoconstriction due to prolonged hypoxic episodes of $\mathrm{SpO}_{2} \leq 85 \%$ but, also, the effect of oxygen toxicity due to hyperoxic episodes $>97 \%[225,229]$.

A recent retrospective cohort study analyzed the effect of a first-line diuretic therapy in infants with BPD associated PH with substantial improvement in respiratory symptoms within one week in $90 \%$ of treated infants but without a difference in mortality or NDO [227]. It has to be mentioned that all infants in this cohort received a high total fluid intake of 155 to $158 \mathrm{~mL} / \mathrm{kg} / \mathrm{d}$. As mentioned in Section Fluid Management, a more restrictive fluid regimen should be considered before diuretic therapy or at least after the start of diuretic therapy (thiazide plus spironolactone), as suggested by EPPVDN, as long as the cardiac preload is adequate [225]. In the case of disease progression, pulmonary vasodilator therapy should be considered after ruling out a pulmonary vein stenosis, which is often associated with premature birth $[223,225-227,230]$. Phosphodiesterase-5 inhibitors as sildenafil have been examined in retrospective cohorts, but there has been no evidence from RCTs or prospective 
studies exists regarding BPD-associated PH treatment with sildenafil so far. Results of a meta-analysis show an improvement in respiratory scores in 15\% within two-seven days and an improvement in $69 \%$ patients regarding echocardiographic parameters of $\mathrm{PH}$ within one to six months without reports on serious side effects [231]. This is important, as the Food and Drug Administration (FDA) in 2012 gave an official warning on the use of sildenafil in children, especially when using higher doses [232]. However, an additional systematic review including RCTs and observational studies found the low-to-moderate dose administration of sildenafil in (older) children with pulmonary hypertension due to various causes efficient and safe [233]. With the results of both meta-analyses and following the recommendation of the EPPVDN consensus statement, the use of sildenafil (initial dose of $1 \mathrm{mg} / \mathrm{kg} / \mathrm{d}$ titrated to a maximum dosage of 4 (to 6-8) $\mathrm{mg} / \mathrm{kg} / \mathrm{d}$ ) in infants with progressive $\mathrm{PH}$ associated to BPD can be considered $[218,225,226]$.

\subsection{Stem Cell Therapy for BPD-An Outlook to a Present Future}

During the last decade, stem cell therapy for the prevention and therapy of neonatal diseases has become a major research focus, with very promising results in preclinical studies [234]. Mesenchymal stem cells (MSC) are the best examined stem cell type and have shown the most potent effect on prevention or treatment of BPD in a network metaanalysis of the preclinical studies [235]. MSC are multipotent stem cells, which can be extracted from bone marrow or adipose tissue or, much easier, with a higher proliferative activity and the potential of autologous therapy from the amniotic hulls, umbilical cord or umbilical cord blood [234,236]. The regenerative mechanism is, in contrast to the first speculations, not by cell replacement (engraftment $<1-5 \%$ ) but seems to depend mostly on paracrine mechanisms $[234,236]$. These consist of bioactive substances as signaling peptides and growths factors, extracellular matrix proteins and exosomes. The latter are membrane-bound vesicles transferring proteins and microRNA into targeted surrounding cells acting with transcriptional and posttranslational modifications in these cells [234]. This explains the evident improvement of alveolarization, angiogenesis and pulmonary arterial remodeling by cell-free therapy with MSC-conditioned media in another meta-analysis of preclinical studies [237]. One very recent study reported on the effect of MSC-conditioned media on structural and functional lung maturation, therefore targeting the lung tissue immaturity itself [238]. The network-meta-analysis still found MSC therapy superior to MSC-conditioned media regarding all four analyzed clinically relevant outcomes (alveolarization, lung angiogenesis, pulmonary hypertension and lung inflammation) [235]. All studies evaluating the safety of MSC-based therapy found no short- or long-term adverse effects, but the results have to be interpreted with caution, as almost exclusively rodent models were used in the included studies [235]. Nonetheless, in 2014, the results of the first human MSC phase I trial administering $10^{7}$ or $2 \times 10^{7}$ human cord blood-derived MSCs intratracheally to nine preterm infants at high risk for BPD were published [239]. MSC therapy was well-tolerated, and a reduction in inflammatory parameters in tracheal aspirates could be shown, as well as a reduction of BPD severity compared to a historical cohort [239]. One infant died due to sepsis at the age of six months, but the two-year follow-up of this phase I trial showed no signs of transplantation-related adverse events, including tumor formation [240]. At the moment of writing the draft of this manuscript (5 February 2021), twelve recruiting or completed phase I and phase II studies evaluating the prevention or therapy of BPD with stem cells or stem cell-conditioned media have been registered at ClinicalTrials.gov, plus an additional four follow-up studies. 


\section{Recommendations for the Everyday BPD Management Based on the Presented Evidence}

In the following paragraphs, we present evidence-based recommendations for BPD management in very preterm infants. Additionally, Table 2 summarize the recommendations for BPD prevention, while Table 3 includes the recommendations for BPD therapy.

\subsection{Antenatal Corticosteroids}

ANS is an effective method in the reduction of mortality and the combined outcome of BPD or death in very preterm infants. Timing of ANS is an issue, as ANS is most effective in an interval of $>24 \mathrm{~h}$ to seven days after the last injection. As the outcome is significantly better with an ANS course longer than seven days compared to none, ANS should be administrated in case of impending preterm birth before 34 weeks of gestation. A rescue retreatment should be considered if the first course has been completed more than one week before.

\subsection{Surfactant-Replacement Therapy}

Surfactant-replacement therapy is an essential therapy in neonatology and improved survival rates of much more immature preterm infants. Animal derived surfactant seems to be superior to synthetic surfactant, and there is weak evidence that poractant is superior to bovine surfactant. More important is the way of surfactant administration, especially in regard to the recommended noninvasive respiratory support: recent meta-analyses consistently show the superiority of LISA/MIST compared to invasive surfactant administration regarding mortality, combined BPD or death and BPD development. Therefore, this should be the preferred way of surfactant administration if the expertise of the attending physician regarding this technique is sufficient.

\subsection{Caffeine}

Based on the currently available high-level evidence from RCTs, mainly CAP, treatment with caffeine with the intention to reduce the risk of BPD can be recommended. This recommendation focuses on extremely preterm infants, since this patient group was enrolled in CAP and is also the patient group with the highest risk of developing BPD. To start caffeine treatment in the first three days of life may be considered, especially in those infants that already receive noninvasive ventilatory support, since early caffeine may help to avoid invasive ventilation in these infants.

\subsection{Ventilation Strategies}

If possible by the use of noninvasive respiratory support, mechanical ventilation should be avoided. Unfortunately, neither an optimal PEEP level for a group of infants based on pathology or patient characteristics, nor a strategy to identify the optimal level for an individual infant, could be established so far [77]. Whenever mechanical ventilation was inevitable, lung-protective ventilation strategies should be applied, and the goal should be the earliest reasonable extubation.

\subsubsection{High-Frequency Oscillation Ventilation}

As modern respirators have evolved in terms of synchronization and tidal volume measurements, a comparison between volume-targeted ventilation modes and HFOV might be more relevant to neonatologists in the 2020s [84]. In the absence of valid recent data and with relatively small differences from meta-analyses of RCTs performed in the last four decades, it is difficult to make clear recommendations. 


\subsubsection{Volume-Targeted-Ventilation (VTV)}

Although the evidence for the most vulnerable group of ELBW infants is not as strong as for all newborn infants together, we believe it is strong enough to use VTV as the preferred mode of conventional ventilation, whenever it is possible.

\subsubsection{Permissive Hypercapnia}

Although not supported by clear evidence, permissive hypercapnia is widely used in European NICUs [241]. While the randomized studies demonstrated difficulties in strict protocol adherence, probably because some infants require different $\mathrm{pCO}_{2}$ targets than those prescribed by randomization, there is no evidence to support the universal $\mathrm{pCO}_{2}$ target of $45 \mathrm{mmHg}$ for every preterm infant. Most likely, there is a threshold beyond which intensifying the pressure, tidal volume or amplitude is increasingly harmful, and it might be wiser to let $\mathrm{pCO}_{2}$ increase a bit higher instead of pushing ventilator settings further and further-but we still do not know where this threshold is and if it is the same for every infant.

\subsubsection{Supplemental Oxygen}

Oxygen therapy in very preterm infants remains a balancing act. Oxygen saturation levels in the low 90 s\% should be targeted, as lower ranges (85-89\%) were associated with an increased mortality [97]. In infants with suspected or proven pulmonary hypertension, the inspired fraction of oxygen should aim at higher oxygen saturation levels of $93 \%$ and $95 \%$, respectively.

\subsection{Tracheostomy Placement}

There is insufficient evidence for the criteria and/or optimal timing of tracheostomy. Infants with persisting ventilator-dependency (mechanical ventilation or high-level noninvasive respiratory support) beyond the neonatal period might profit from a reduced sedative medication after tracheostomy and the possibility of more parent-child interaction and development supporting therapies and environment.

\subsection{Postnatal Corticosteroids}

CS have a beneficial effect on the development of BPD but are associated with severe short-term side effects and no clear-cut effect on the neurodevelopmental outcome. There is evidence that dexamethasone is more efficient than hydrocortisone, while the latter is potentially associated with lesser impact on NDO. The use of systemic CS, preferably dexamethasone, should be limited to repeated failure to extubate due to developing BPD. Increasing evidence exists for the BPD prevention with topic CS administration, yet with the unclear nonsignificant increase in mortality of NEurOSIS and paucity of long-term data after intratracheal instillation of CS, at this moment, the routine use of topic CS treatment cannot be recommended.

\subsection{Inhaled Nitric Oxide (iNO)}

There is no indication for iNO as a general prophylactic therapy to prevent BPD. It is unclear, whether there is increased risk for severe intraventricular hemorrhage for early rescue therapy, so iNO should be restricted for the most severe cases of hypoxemic respiratory failure. Only for preterm infants of African American descent, high dose prophylactic therapy should be considered. 


\subsection{Inhaled Bronchodilators}

There is too little evidence to show positive or negative effects of bronchodilators for prevention of chronic lung disease, and thus, at the moment, inhaled bronchodilators should not be used routinely for this indication.

\subsection{Macrolides}

A beneficial effect of macrolides on BPD—in particular, in ventilated Ureaplasmapositive infants treated for a longer duration-cannot be ruled out. However, as long as this is not proven as a primary endpoint in rigorously conducted RCTs of sufficient size, and as long as safety concerns are not sufficiently addressed, we do not recommend routine treatment with macrolides.

\subsection{Patent Ductus Arteriosus}

Beside restrictive fluid intake (Section Fluid Management) and application of continuous positive airway pressure, no uniform recommendation regarding the management of the PDA can be given, as some particularly vulnerable patients may benefit from earlytargeted treatment, and some infants may even profit from surgical ligation if pharmacological treatment fails. Therefore, Hamrick et al. presented a differentiated treatment algorithm considering demographic factors, echocardiographic findings and clinical assessment [157].

\subsection{Fluid-Management and Nutrition}

Moderate early restrictive fluid management in infants with hemodynamically significant PDA and/or high risk for BPD is recommended with a fluid intake of approximately $60-80 \mathrm{~mL} / \mathrm{kg}$ on first day stepwise increasing by $10-20 \mathrm{~mL} / \mathrm{kg}$ to a total of $130 \mathrm{~mL} / \mathrm{kg} / \mathrm{d}$. Fluid balance, diuresis and weight loss should be carefully monitored especially during parenteral fluids are given to the infant.

To avoid unnecessary exposure to diuretics, fluid restriction should be continued in infants with signs of developing BPD as increasing need for supplemental oxygen or mean airway pressure. The physician has to weigh benefits against potential harms of a diuretic therapy. A longer treatment with thiazide plus spironolactone should only be administered if a beneficial effect on pulmonary mechanics as reduction of supplemental oxygen or mean airway pressure occurs during probatory treatment (with loop diuretics or diuretics acting on the distal tubule).

Sufficient energy supply has to be guaranteed even during reduction of water intake. To address the higher energy consumption in established BPD, a daily energy intake of $>135 \mathrm{kcal} / \mathrm{kg}$ is recommended.

Early enteral feeding preferably with maternal breast milk or human donor milk may reduce development of BPD. Individualized fortification of human milk is superior to standardized fortification regarding growth parameters but there is insufficient evidence regarding BPD development.

\subsection{Vitamin A}

Taking into account the presumably small effect size and the sufficient enteral absorption, we believe it is not justified our patients to repeated intramuscular injections. Until the results of NeoVitaA tell us otherwise, we recommend supplementation of vitamin A as part of the lipid infusion in parenterally fed infants and with a water-soluble preparation in enterally fed infants in the upper range of current guidelines [242,243]. 
Table 2. Preventive strategies for BPD.

\section{Evidence-Based Preventive Strategies for BPD}

Antenatal corticosteroids

Surfactant replacement therapy

Caffeine

Systemic postnatal corticosteroids

Fluid management and nutrition

\section{Preventive strategies for BPD with unclear evidence}

High-frequency oscillation ventilation

Permissive hypercapnia

- Unclear (and likely individually different) threshold for the targeted $\mathrm{pCO}_{2}$ level.

Topic corticosteroids

- Inhaled CS effectively prevented BPD but with an unclear (nonsignificant) increase in mortality in the largest NEurOSIS trial.
- Avoid invasive ventilation by the use of noninvasive respiratory support.

- $\quad$ Lung-protective ventilation: volume-targeted ventilation.

- Supplemental oxygen-targeting $\mathrm{SpO}_{2}$ levels in low $90 \mathrm{~s} \%$, with higher thresholds only in the case of pulmonary hypertension.

- Aim at early extubation.

- Dexamethasone is more effective than hydrocortisone, but the latter might have a lesser impact on neurodevelopmental outcome.

- Limit systemic postnatal corticosteroid therapy to facilitate successful extubation only after repeated extubation failure.
- Moderate early restrictive fluid management starting from $60-80 \mathrm{~mL} / \mathrm{kg} / \mathrm{d}$ and increasing to $130 \mathrm{~mL} / \mathrm{kg} / \mathrm{d}$. Careful monitoring of diuresis and weight loss is recommended.

- Human milk, especially own mother's milk, may prevent BPD development.

- Provide parenteral or enteral vitamin A supplementation in the upper range of the current guidelines.

- $\quad$ Lack of RCTs comparing volume-targeted ventilation and HFOV

- Insufficient evidence for the efficiency and long-term safety for the routine use of

Macrolides macrolides.

- $\quad$ Treat infants with proven Ureaplasma spp. pneumonia with macrolides.

Patent ductus arteriosus

- Apply fluid restriction and sufficient positive airway pressure to reduce the risk for relevant PDA. No uniform recommendation can be given for PDA treatment.

- $\quad$ Risk-adapted screening and treatment algorithms have been recently published. 
Table 2. Cont.

\section{Preventive strategies for BPD with a lack of evidence}

- No prophylactic therapy of iNO.

- Infants of African-American descent might profit from high-dose prophylactic

Inhaled nitric oxide therapy.

- $\quad$ iNO should be restricted to severe hypoxemic respiratory failure with echocardiographic signs of elevated pulmonary vascular resistance.

Inhaled bronchodilators

- $\quad$ Lack of evidence for the preventive use of inhaled bronchodilators.

Abbreviations: ANS antenatal corticosteroids, GA gestational age, LISA less invasive surfactant administration, MIST minimally invasive surfactant therapy, BPD bronchopulmonary dysplasia, RCT randomized controlled trial, HFOV high-frequency oscillation ventilation, $p \mathrm{CO}_{2}$ partial pressure of carbon dioxide, NEurOSIS "Neonatal European Study of Inhaled Steroids", $i N O$ inhaled nitric oxide.

\subsection{BPD-Associated Pulmonary Hypertension}

Echocardiographic screening for BPD-associated PH should be performed at 36 weeks PMA and, eventually, in pre-discharge infants with a high risk for PH. In these infants, outpatient cardiologic follow-up is recommended. The treatment of BPD-associated PH should include higher targeted oxygen saturation and restrictive fluid management. Diuretic therapy with thiazide and spironolactone are first-line pharmacological treatments; in the case of disease progression, low-to-moderate dose sildenafil therapy should be considered.

\subsection{Stem Cell Therapy}

Despite the promising results, the administration of MSC or MSC-conditioned media for the treatment of BPD should be limited to controlled trials until efficacy and, especially, long-term safety have been proven by sufficiently powered randomized controlled trials.

Table 3. Therapeutic strategies for BPD.

\section{Evidence-Based Therapeutic Strategies for BPD}

- Continue fluid restriction in infants showing early signs of developing BPD (e.g.,

Fluid management and nutrition increasing the oxygen demand or respiratory support) or proven BPD.

- Higher-energy expenditure necessitates a higher caloric intake of $>135$ $\mathrm{kcal} / \mathrm{kg} / \mathrm{d}$ by an increased fortification of milk.

Systemic postnatal corticosteroids

- Prevention and therapy cannot be well-distinguished; therefore, the recommendation is the same as written above.

\section{Therapeutic strategies for BPD with unclear evidence}

- Diuretics may improve the pulmonary mechanics. Consider long-term diuretic therapy with thiazide and spironolactone if a probatory therapy with furosemide is effective.

- $\quad$ First-line therapy in BPD-associated PH.

Stem cell therapy

- Despite promising results, stem cell therapy should be limited in clinical trials until sufficient evidence for the long-term safety and effects is presented. 


\title{
4. Conclusions
}

BPD management remains an extremely challenging task, and the presented strategies for everyday work in a neonatal intensive care unit should be considered to improve the survival and outcome of very preterm infants.

\begin{abstract}
Author Contributions: All authors contributed significantly to the manuscript. The conceptualization of this review was performed by D.B. and M.B.B., T.M. wrote the first draft of the following paragraphs: antenatal steroids prophylaxis, surfactant replacement therapy, postnatal corticosteroids, fluid management and nutrition, patent ductus arteriosus, pulmonary hypertension and mesenchymal stem cell therapy. D.B. wrote the first draft of the following paragraphs: caffeine and bronchodilators. M.B.B. wrote the first draft of the following paragraphs: vitamin A, macrolide therapy, inhaled nitric oxide and ventilation strategies. All authors have read and agreed to the published version of the manuscript.
\end{abstract}

Funding: This research received no external funding.

Institutional Review Board Statement: Not applicable, no original data were processed in this review.

Informed Consent Statement: Not applicable.

Data Availability Statement: Not applicable, no original data were processed in this review.

Conflicts of Interest: The authors declare no conflict of interest.

\section{References}

1. Northway, W.H., Jr.; Rosan, R.C.; Porter, D.Y. Pulmonary disease following respirator therapy of hyaline-membrane disease. Bronchopulmonary dysplasia. N. Engl. J. Med. 1967, 276, 357-368. [CrossRef] [PubMed]

2. Shennan, A.T.; Dunn, M.S.; Ohlsson, A.; Lennox, K.; Hoskins, E.M. Abnormal pulmonary outcomes in premature infants: Prediction from oxygen requirement in the neonatal period. Pediatrics 1988, 82, 527-532. [PubMed]

3. Jobe, A.H.; Bancalari, E. Bronchopulmonary dysplasia. Am. J. Respir. Crit. Care Med. 2001, 163, 1723-1729. [CrossRef] [PubMed]

4. Jensen, E.A.; Dysart, K.; Gantz, M.G.; McDonald, S.; Bamat, N.A.; Keszler, M.; Kirpalani, H.; Laughon, M.M.; Poindexter, B.B.; Duncan, A.F.; et al. The Diagnosis of Bronchopulmonary Dysplasia in Very Preterm Infants. An Evidence-based Approach. Am. J. Respir. Crit. Care Med. 2019, 200, 751-759. [CrossRef] [PubMed]

5. Jensen, E.A.; Schmidt, B. Epidemiology of bronchopulmonary dysplasia. Birth Defects Res. A Clin. Mol. Teratol. 2014, 100, 145-157. [CrossRef]

6. Fanaroff, A.A.; Stoll, B.J.; Wright, L.L.; Carlo, W.A.; Ehrenkranz, R.A.; Stark, A.R.; Bauer, C.R.; Donovan, E.F.; Korones, S.B.; Laptook, A.R.; et al. Trends in neonatal morbidity and mortality for very low birthweight infants. Am. J. Obstet. Gynecol. 2007, 196, 147.e1-147.e8. [CrossRef] [PubMed]

7. Stoll, B.J.; Hansen, N.I.; Bell, E.F.; Walsh, M.C.; Carlo, W.A.; Shankaran, S.; Laptook, A.R.; Sanchez, P.J.; Van Meurs, K.P.; Wyckoff, M.; et al. Trends in Care Practices, Morbidity, and Mortality of Extremely Preterm Neonates, 1993-2012. JAMA 2015, 314, 1039-1051. [CrossRef]

8. Jobe, A.J. The new BPD: An arrest of lung development. Pediatr. Res. 1999, 46, 641-643. [CrossRef]

9. Thebaud, B.; Goss, K.N.; Laughon, M.; Whitsett, J.A.; Abman, S.H.; Steinhorn, R.H.; Aschner, J.L.; Davis, P.G.; McGrath-Morrow, S.A.; Soll, R.F.; et al. Bronchopulmonary dysplasia. Nat. Rev. Dis. Primers. 2019, 5, 78. [CrossRef]

10. DeVries, L.B.; Heyne, R.J.; Ramaciotti, C.; Brown, L.S.; Jaleel, M.A.; Kapadia, V.S.; Burchfield, P.J.; Brion, L.P. Mortality among infants with evolving bronchopulmonary dysplasia increases with major surgery and with pulmonary hypertension. J. Perinatol. 2017, 37, 1043-1046. [CrossRef]

11. Gallini, F.; Coppola, M.; De Rose, D.U.; Maggio, L.; Arena, R.; Romano, V.; Cota, F.; Ricci, D.; Romeo, D.M.; Mercuri, E.M.; et al. Neurodevelopmental outcomes in very preterm infants: The role of severity of Bronchopulmonary Dysplasia. Early Hum. Dev. 2021, 152, 105275. [CrossRef]

12. Liggins, G.C.; Howie, R.N. A controlled trial of antepartum glucocorticoid treatment for prevention of the respiratory distress syndrome in premature infants. Pediatrics 1972, 50, 515-525.

13. Crowley, P.; Chalmers, I.; Keirse, M.J. The effects of corticosteroid administration before preterm delivery: An overview of the evidence from controlled trials. Br. J. Obstet. Gynaecol. 1990, 97, 11-25. [CrossRef]

14. Effect of corticosteroids for fetal maturation on perinatal outcomes. NIH Consens. Statement 1994, 12, 1-24.

15. Gilstrap, L.C.; Christensen, R.; Clewell, W.H.; D'Alton, M.E.; Davidson, E.C.; Escobedo, M.B.; Gjerdingen, D.K.; GoddardFinegold, J.; Goldenberg, R.L.; Grimes, D.A.; et al. Effect of corticosteroids for fetal maturation on perinatal outcomes. NIH Consensus Development Panel on the Effect of Corticosteroids for Fetal Maturation on Perinatal Outcomes. JAMA 1995, 273, 413-418. [CrossRef] 
16. Roberts, D.; Brown, J.; Medley, N.; Dalziel, S.R. Antenatal corticosteroids for accelerating fetal lung maturation for women at risk of preterm birth. Cochrane Database Syst. Rev. 2017, 3, CD004454. [CrossRef] [PubMed]

17. Manktelow, B.N.; Lal, M.K.; Field, D.J.; Sinha, S.K. Antenatal corticosteroids and neonatal outcomes according to gestational age: A cohort study. Arch. Dis. Child. Fetal Neonatal Ed. 2010, 95, F95-F98. [CrossRef] [PubMed]

18. Mori, R.; Kusuda, S.; Fujimura, M.; Neonatal Research Network Japan. Antenatal corticosteroids promote survival of extremely preterm infants born at 22 to 23 weeks of gestation. J. Pediatr. 2011, 159, 110-114.e1. [CrossRef] [PubMed]

19. Melamed, N.; Shah, J.; Yoon, E.W.; Pelausa, E.; Lee, S.K.; Shah, P.S.; Murphy, K.E.; Canadian Neonatal Network Investigators. The role of antenatal corticosteroids in twin pregnancies complicated by preterm birth. Am. J. Obstet. Gynecol. 2016, 215, 482.e1-482.e9. [CrossRef]

20. Blankenship, S.A.; Brown, K.E.; Simon, L.E.; Stout, M.J.; Tuuli, M.G. Antenatal corticosteroids in preterm small-for-gestational age infants: A systematic review and meta-analysis. Am. J. Obstet. Gynecol. MFM 2020, 2, 100215. [CrossRef] [PubMed]

21. Deshmukh, M.; Patole, S. Antenatal corticosteroids in impending preterm deliveries before 25 weeks' gestation. Arch. Dis. Child. Fetal Neonatal Ed. 2018, 103, F173-F176. [CrossRef]

22. Sasaki, Y.; Ikeda, T.; Nishimura, K.; Katsuragi, S.; Sengoku, K.; Kusuda, S.; Fujimura, M. Association of antenatal corticosteroids and the mode of delivery with the mortality and morbidity of infants weighing less than $1500 \mathrm{~g}$ at birth in Japan. Neonatology 2014, 106, 81-86. [CrossRef] [PubMed]

23. Wong, D.; Abdel-Latif, M.; Kent, A.; NICUS Network. Antenatal steroid exposure and outcomes of very premature infants: A regional cohort study. Arch. Dis. Child. Fetal Neonatal Ed. 2014, 99, F12-F20. [CrossRef] [PubMed]

24. Figueras-Aloy, J.; Serrano, M.M.; Rodriguez, J.P.; Perez, C.F.; Serradilla, V.R.; Jimenez, J.Q.; Gonzalez, R.J.; The SEN1500 Spanish Neonatal Network. Antenatal glucocorticoid treatment decreases mortality and chronic lung disease in survivors among $23-$ to 28-week gestational age preterm infants. Am. J. Perinatol. 2005, 22, 441-448. [CrossRef]

25. Melamed, N.; Shah, J.; Soraisham, A.; Yoon, E.W.; Lee, S.K.; Shah, P.S.; Murphy, K.E. Association Between Antenatal Corticosteroid Administration-to-Birth Interval and Outcomes of Preterm Neonates. Obstet. Gynecol. 2015, 125, 1377-1384. [CrossRef] [PubMed]

26. Goldstein, N.D.; Kenaley, K.M.; Locke, R.; Paul, D.A. The Joint Effects of Antenatal Steroids and Gestational Age on Improved Outcomes in Neonates. Matern. Child. Health J. 2018, 22, 384-390. [CrossRef]

27. Battarbee, A.N.; Ros, S.T.; Esplin, M.S.; Biggio, J.; Bukowski, R.; Parry, S.; Zhang, H.; Huang, H.; Andrews, W.; Saade, G.; et al. Optimal timing of antenatal corticosteroid administration and preterm neonatal and early childhood outcomes. Am. J. Obstet. Gynecol. MFM 2020, 2. [CrossRef]

28. Travers, C.P.; Carlo, W.A.; McDonald, S.A.; Das, A.; Bell, E.F.; Ambalavanan, N.; Jobe, A.H.; Goldberg, R.N.; D’Angio, C.T.; Stoll, B.J.; et al. Mortality and pulmonary outcomes of extremely preterm infants exposed to antenatal corticosteroids. Am. J. Obstet. Gynecol. 2018, 218, 130.e1-130.e13. [CrossRef]

29. Crowther, C.A.; McKinlay, C.J.; Middleton, P.; Harding, J.E. Repeat doses of prenatal corticosteroids for women at risk of preterm birth for improving neonatal health outcomes. Cochrane Database Syst. Rev. 2015, CD003935. [CrossRef]

30. Banks, B.A.; Cnaan, A.; Morgan, M.A.; Parer, J.T.; Merrill, J.D.; Ballard, P.L.; Ballard, R.A. Multiple courses of antenatal corticosteroids and outcome of premature neonates. North American Thyrotropin-Releasing Hormone Study Group. Am. J. Obstet. Gynecol. 1999, 181, 709-717. [CrossRef]

31. Fujiwara, T.; Maeta, H.; Chida, S.; Morita, T.; Watabe, Y.; Abe, T. Artificial surfactant therapy in hyaline-membrane disease. Lancet 1980, 1, 55-59. [CrossRef]

32. Hennes, H.M.; Lee, M.B.; Rimm, A.A.; Shapiro, D.L. Surfactant replacement therapy in respiratory distress syndrome. Metaanalysis of clinical trials of single-dose surfactant extracts. Am. J. Dis. Child. 1991, 145, 102-104. [CrossRef]

33. Soll, R.F. Synthetic surfactant for respiratory distress syndrome in preterm infants. Cochrane Database Syst. Rev. 2000, CD001149. [CrossRef]

34. Soll, R.F. Prophylactic natural surfactant extract for preventing morbidity and mortality in preterm infants. Cochrane Database Syst. Rev. 2000, CD000511. [CrossRef]

35. Soll, R.; Ozek, E. Prophylactic protein free synthetic surfactant for preventing morbidity and mortality in preterm infants. Cochrane Database Syst. Rev. 2010, CD001079. [CrossRef]

36. Seger, N.; Soll, R. Animal derived surfactant extract for treatment of respiratory distress syndrome. Cochrane Database Syst. Rev. 2009, CD007836. [CrossRef] [PubMed]

37. Moya, F.R.; Gadzinowski, J.; Bancalari, E.; Salinas, V.; Kopelman, B.; Bancalari, A.; Kornacka, M.K.; Merritt, T.A.; Segal, R.; Schaber, C.J.; et al. A multicenter, randomized, masked, comparison trial of lucinactant, colfosceril palmitate, and beractant for the prevention of respiratory distress syndrome among very preterm infants. Pediatrics 2005, 115, 1018-1029. [CrossRef] [PubMed]

38. Ardell, S.; Pfister, R.H.; Soll, R. Animal derived surfactant extract versus protein free synthetic surfactant for the prevention and treatment of respiratory distress syndrome. Cochrane Database Syst. Rev. 2015, 8, CD000144. [CrossRef] [PubMed]

39. Pfister, R.H.; Soll, R.F.; Wiswell, T. Protein containing synthetic surfactant versus animal derived surfactant extract for the prevention and treatment of respiratory distress syndrome. Cochrane Database Syst. Rev. 2007, CD006069. [CrossRef]

40. Singh, N.; Halliday, H.L.; Stevens, T.P.; Suresh, G.; Soll, R.; Rojas-Reyes, M.X. Comparison of animal-derived surfactants for the prevention and treatment of respiratory distress syndrome in preterm infants. Cochrane Database Syst. Rev. 2015, CD010249. [CrossRef] [PubMed] 
41. Sanchez Luna, M.; Bacher, P.; Unnebrink, K.; Martinez-Tristani, M.; Ramos Navarro, C. Beractant and poractant alfa in premature neonates with respiratory distress syndrome: A systematic review of real-world evidence studies and randomized controlled trials. J. Perinatol. 2020, 40, 1121-1134. [CrossRef]

42. Ramanathan, R.; Rasmussen, M.R.; Gerstmann, D.R.; Finer, N.; Sekar, K.; The North American Study Group. A randomized, multicenter masked comparison trial of poractant alfa (Curosurf) versus beractant (Survanta) in the treatment of respiratory distress syndrome in preterm infants. Am. J. Perinatol. 2004, 21, 109-119. [CrossRef]

43. Mirzarahimi, M.; Barak, M. Comparison efficacy of Curosurf and Survanta in preterm infants with respiratory distress syndrome. Pak. J. Pharm. Sci. 2018, 31, 469-472.

44. Najafian, B.; Karimi-Sari, H.; Khosravi, M.H.; Nikjoo, N.; Amin, S.; Shohrati, M. Comparison of efficacy and safety of two available natural surfactants in Iran, Curosurf and Survanta in treatment of neonatal respiratory distress syndrome: A randomized clinical trial. Contemp. Clin. Trials Commun. 2016, 3, 55-59. [CrossRef] [PubMed]

45. Baroutis, G.; Kaleyias, J.; Liarou, T.; Papathoma, E.; Hatzistamatiou, Z.; Costalos, C. Comparison of three treatment regimens of natural surfactant preparations in neonatal respiratory distress syndrome. Eur. J. Pediatr. 2003, 162, 476-480. [CrossRef] [PubMed]

46. Speer, C.P.; Gefeller, O.; Groneck, P.; Laufkotter, E.; Roll, C.; Hanssler, L.; Harms, K.; Herting, E.; Boenisch, H.; Windeler, J.; et al. Randomised clinical trial of two treatment regimens of natural surfactant preparations in neonatal respiratory distress syndrome. Arch. Dis. Child. Fetal Neonatal Ed. 1995, 72, F8-F13. [CrossRef] [PubMed]

47. Saeedi, R.; Hamedi, A.; Javadi, A.; Gholami Robatsangi, M.; Dinparvar, S.K. Comparison of side effect of Survanta and Curosurf in decreasing mortality due to respiratory distress syndrome (RDS) in premature infants admitted in NICU of Ghaem Hospital on 2006-2008. Iran. J. Neonatol. 2013, 4, 7-12.

48. Isayama, T.; Chai-Adisaksopha, C.; McDonald, S.D. Noninvasive Ventilation With vs. Without Early Surfactant to Prevent Chronic Lung Disease in Preterm Infants: A Systematic Review and Meta-analysis. JAMA Pediatr. 2015, 169, 731-739. [CrossRef] [PubMed]

49. Vento, G.; Ventura, M.L.; Pastorino, R.; van Kaam, A.H.; Carnielli, V.; Cools, F.; Dani, C.; Mosca, F.; Polglase, G.; Tagliabue, P.; et al. Lung recruitment before surfactant administration in extremely preterm neonates with respiratory distress syndrome (IN-REC-SUR-E): A randomised, unblinded, controlled trial. Lancet Respir. Med. 2021, 9, 159-166. [CrossRef]

50. Aldana-Aguirre, J.C.; Pinto, M.; Featherstone, R.M.; Kumar, M. Less invasive surfactant administration versus intubation for surfactant delivery in preterm infants with respiratory distress syndrome: A systematic review and meta-analysis. Arch. Dis. Child. Fetal Neonatal Ed. 2017, 102, F17-F23. [CrossRef]

51. Rigo, V.; Lefebvre, C.; Broux, I. Surfactant instillation in spontaneously breathing preterm infants: A systematic review and meta-analysis. Eur J. Pediatr 2016, 175, 1933-1942. [CrossRef]

52. Panza, R.; Laforgia, N.; Bellos, I.; Pandita, A. Systematic review found that using thin catheters to deliver surfactant to preterm neonates was associated with reduced bronchopulmonary dysplasia and mechanical ventilation. Acta Paediatr. 2020, 109, 2219-2225. [CrossRef]

53. Isayama, T.; Iwami, H.; McDonald, S.; Beyene, J. Association of Noninvasive Ventilation Strategies With Mortality and Bronchopulmonary Dysplasia Among Preterm Infants: A Systematic Review and Meta-analysis. JAMA 2016, 316, 611-624. [CrossRef]

54. Bellos, I.; Fitrou, G.; Panza, R.; Pandita, A. Comparative efficacy of methods for surfactant administration: A network metaanalysis. Arch. Dis. Child. Fetal Neonatal Ed. 2021. [CrossRef]

55. Dunwiddie, T.V.; Masino, S.A. The role and regulation of adenosine in the central nervous system. Annu. Rev. Neurosci. 2001, 24, 31-55. [CrossRef]

56. Fredholm, B.B.; Yang, J.; Wang, Y. Low, but not high, dose caffeine is a readily available probe for adenosine actions. Mol. Asp. Med. 2017, 55, 20-25. [CrossRef]

57. Bassler, D.; Schmidt, B. Strategies for prevention of apneic episodes in preterm infants: Are respiratory stimulants worth the risk? In The Newborn Lung. Neonatology Questions and Controversies; Bancalari, E., Ed.; Saunders, Elsevier: Philadelphia, PA, USA, 2008; pp. 461-476.

58. Schmidt, B.; Roberts, R.S.; Davis, P.; Doyle, L.W.; Barrington, K.J.; Ohlsson, A.; Solimano, A.; Tin, W.; Caffeine for Apnea of Prematurity Trial Group. Caffeine therapy for apnea of prematurity. N. Engl. J. Med. 2006, 354, 2112-2121. [CrossRef]

59. Sweet, D.G.; Carnielli, V.; Greisen, G.; Hallman, M.; Ozek, E.; Te Pas, A.; Plavka, R.; Roehr, C.C.; Saugstad, O.D.; Simeoni, U.; et al. European Consensus Guidelines on the Management of Respiratory Distress Syndrome-2019 Update. Neonatology 2019, 115, 432-450. [CrossRef]

60. Lodha, A.; Entz, R.; Synnes, A.; Creighton, D.; Yusuf, K.; Lapointe, A.; Yang, J.; Shah, P.S.; The investigators of the Canadian Neonatal Network; the Canadian Neonatal Follow-up Network. Early Caffeine Administration and Neurodevelopmental Outcomes in Preterm Infants. Pediatrics 2019, 143. [CrossRef]

61. Kua, K.P.; Lee, S.W. Systematic review and meta-analysis of clinical outcomes of early caffeine therapy in preterm neonates. Br. J. Clin. Pharmacol. 2017, 83, 180-191. [CrossRef]

62. Vliegenthart, R.; Miedema, M.; Hutten, G.J.; van Kaam, A.H.; Onland, W. High versus standard dose caffeine for apnoea: A systematic review. Arch. Dis. Child. Fetal Neonatal Ed. 2018, 103, F523-F529. [CrossRef]

63. Brattstrom, P.; Russo, C.; Ley, D.; Bruschettini, M. High-versus low-dose caffeine in preterm infants: A systematic review and meta-analysis. Acta Paediatr. 2019, 108, 401-410. [CrossRef] 
64. Chen, J.; Jin, L.; Chen, X. Efficacy and Safety of Different Maintenance Doses of Caffeine Citrate for Treatment of Apnea in Premature Infants: A Systematic Review and Meta-Analysis. Biomed Res. Int. 2018, 2018, 9061234. [CrossRef]

65. Pakvasa, M.A.; Saroha, V.; Patel, R.M. Optimizing Caffeine Use and Risk of Bronchopulmonary Dysplasia in Preterm Infants: A Systematic Review, Meta-analysis, and Application of Grading of Recommendations Assessment, Development, and Evaluation Methodology. Clin. Perinatol. 2018, 45, 273-291. [CrossRef]

66. De Rose, D.U.; Cairoli, S.; Dionisi, M.; Santisi, A.; Massenzi, L.; Goffredo, B.M.; Dionisi-Vici, C.; Dotta, A.; Auriti, C. Therapeutic Drug Monitoring Is a Feasible Tool to Personalize Drug Administration in Neonates Using New Techniques: An Overview on the Pharmacokinetics and Pharmacodynamics in Neonatal Age. Int. J. Mol. Sci. 2020, 21, 5898. [CrossRef]

67. Moschino, L.; Zivanovic, S.; Hartley, C.; Trevisanuto, D.; Baraldi, E.; Roehr, C.C. Caffeine in preterm infants: Where are we in 2020? ERJ Open Res. 2020, 6. [CrossRef]

68. Bjorklund, L.J.; Ingimarsson, J.; Curstedt, T.; John, J.; Robertson, B.; Werner, O.; Vilstrup, C.T. Manual ventilation with a few large breaths at birth compromises the therapeutic effect of subsequent surfactant replacement in immature lambs. Pediatr. Res. 1997, 42, 348-355. [CrossRef]

69. Dreyfuss, D.; Saumon, G. Ventilator-induced lung injury: Lessons from experimental studies. Am. J. Respir. Crit. Care Med. 1998, 157, 294-323. [CrossRef]

70. Owen, L.S.; Manley, B.J.; Davis, P.G.; Doyle, L.W. The evolution of modern respiratory care for preterm infants. Lancet 2017, 389, 1649-1659. [CrossRef]

71. Reiterer, F.; Schwaberger, B.; Freidl, T.; Schmolzer, G.; Pichler, G.; Urlesberger, B. Lung-protective ventilatory strategies in intubated preterm neonates with RDS. Paediatr. Respir. Rev. 2017, 23, 89-96. [CrossRef]

72. Greenough, A.; Rossor, T.E.; Sundaresan, A.; Murthy, V.; Milner, A.D. Synchronized mechanical ventilation for respiratory support in newborn infants. Cochrane Database Syst. Rev. 2016, 9, CD000456. [CrossRef]

73. Cools, F.; Offringa, M.; Askie, L.M. Elective high frequency oscillatory ventilation versus conventional ventilation for acute pulmonary dysfunction in preterm infants. Cochrane Database Syst. Rev. 2015, CD000104. [CrossRef] [PubMed]

74. Bhuta, T.; Henderson-Smart, D.J. Elective high frequency jet ventilation versus conventional ventilation for respiratory distress syndrome in preterm infants. Cochrane Database Syst. Rev. 2000, CD000328. [CrossRef] [PubMed]

75. Ethawi, Y.H.; Abou Mehrem, A.; Minski, J.; Ruth, C.A.; Davis, P.G. High frequency jet ventilation versus high frequency oscillatory ventilation for pulmonary dysfunction in preterm infants. Cochrane Database Syst. Rev. 2016, CD010548. [CrossRef] [PubMed]

76. Klingenberg, C.; Wheeler, K.I.; McCallion, N.; Morley, C.J.; Davis, P.G. Volume-targeted versus pressure-limited ventilation in neonates. Cochrane Database Syst. Rev. 2017, 10, CD003666. [CrossRef]

77. Bamat, N.; Fierro, J.; Wang, Y.; Millar, D.; Kirpalani, H. Positive end-expiratory pressure for preterm infants requiring conventional mechanical ventilation for respiratory distress syndrome or bronchopulmonary dysplasia. Cochrane Database Syst. Rev. 2019, 2, CD004500. [CrossRef] [PubMed]

78. Kamlin, C.; Davis, P.G. Long versus short inspiratory times in neonates receiving mechanical ventilation. Cochrane Database Syst. Rev. 2004, CD004503. [CrossRef]

79. Woodgate, P.G.; Davies, M.W. Permissive hypercapnia for the prevention of morbidity and mortality in mechanically ventilated newborn infants. Cochrane database Syst. Rev. (Online) 2001, CD002061. [CrossRef]

80. Rossor, T.E.; Hunt, K.A.; Shetty, S.; Greenough, A. Neurally adjusted ventilatory assist compared to other forms of triggered ventilation for neonatal respiratory support. Cochrane Database Syst. Rev. 2017, 10, CD012251. [CrossRef]

81. Schulzke, S.M.; Pillow, J.; Ewald, B.; Patole, S.K. Flow-cycled versus time-cycled synchronized ventilation for neonates. Cochrane Database Syst. Rev. 2010, CD008246. [CrossRef]

82. Cools, F.; Henderson-Smart, D.J.; Offringa, M.; Askie, L.M. Elective high frequency oscillatory ventilation versus conventional ventilation for acute pulmonary dysfunction in preterm infants. Cochrane Database Syst. Rev. 2009, CD000104. [CrossRef]

83. Cools, F.; Askie, L.M.; Offringa, M.; Asselin, J.M.; Calvert, S.A.; Courtney, S.E.; Dani, C.; Durand, D.J.; Gerstmann, D.R.; Henderson-Smart, D.J.; et al. Elective high-frequency oscillatory versus conventional ventilation in preterm infants: A systematic review and meta-analysis of individual patients' data. Lancet 2010, 375, 2082-2091. [CrossRef]

84. Ganguly, A.; Makkar, A.; Sekar, K. Volume Targeted Ventilation and High Frequency Ventilation as the Primary Modes of Respiratory Support for ELBW Babies: What Does the Evidence Say? Front. Pediatr. 2020, 8, 27. [CrossRef] [PubMed]

85. Rojas-Reyes, M.X.; Orrego-Rojas, P.A. Rescue high-frequency jet ventilation versus conventional ventilation for severe pulmonary dysfunction in preterm infants. Cochrane Database Syst. Rev. 2015, CD000437. [CrossRef]

86. Hernandez, L.A.; Peevy, K.J.; Moise, A.A.; Parker, J.C. Chest wall restriction limits high airway pressure-induced lung injury in young rabbits. J. Appl. Physiol. 1989, 66, 2364-2368. [CrossRef]

87. Keszler, M. Volume-targeted ventilation: One size does not fit all. Evidence-based recommendations for successful use. Arch. Dis. Child. Fetal Neonatal Ed. 2019, 104, F108-F112. [CrossRef]

88. Tuzun, F.; Deliloglu, B.; Cengiz, M.M.; Iscan, B.; Duman, N.; Ozkan, H. Volume Guarantee High-Frequency Oscillatory Ventilation in Preterm Infants With RDS: Tidal Volume and DCO2 Levels for Optimal Ventilation Using Open-Lung Strategies. Front. Pediatr. 2020, 8, 105. [CrossRef]

89. Peng, W.; Zhu, H.; Shi, H.; Liu, E. Volume-targeted ventilation is more suitable than pressure-limited ventilation for preterm infants: A systematic review and meta-analysis. Arch. Dis. Child. Fetal Neonatal Ed. 2014, 99, F158-F165. [CrossRef] 
90. Liu, W.Q.; Xu, Y.; Han, A.M.; Meng, L.J.; Wang, J. A comparative study of two ventilation modes in the weaning phase of preterm infants with respiratory distress syndrome. Zhongguo Dang Dai Er Ke Za Zhi 2018, 20, 729-733.

91. Thome, U.H.; Ambalavanan, N. Permissive hypercapnia to decrease lung injury in ventilated preterm neonates. Semin. Fetal Neonatal Med. 2009, 14, 21-27. [CrossRef]

92. Kaiser, J.R.; Gauss, C.H.; Pont, M.M.; Williams, D.K. Hypercapnia during the first 3 days of life is associated with severe intraventricular hemorrhage in very low birth weight infants. J. Perinatol. 2006, 26, 279-285. [CrossRef] [PubMed]

93. Thome, U.H.; Genzel-Boroviczeny, O.; Bohnhorst, B.; Schmid, M.; Fuchs, H.; Rohde, O.; Avenarius, S.; Topf, H.G.; Zimmermann, A.; Faas, D.; et al. Permissive hypercapnia in extremely low birthweight infants (PHELBI): A randomised controlled multicentre trial. Lancet Respir. Med. 2015, 3, 534-543. [CrossRef]

94. Thome, U.H.; Carroll, W.; Wu, T.J.; Johnson, R.B.; Roane, C.; Young, D.; Carlo, W.A. Outcome of extremely preterm infants randomized at birth to different $\mathrm{PaCO} 2$ targets during the first seven days of life. Biol Neonate 2006, 90, 218-225. [CrossRef]

95. Thome, U.H.; Genzel-Boroviczeny, O.; Bohnhorst, B.; Schmid, M.; Fuchs, H.; Rohde, O.; Avenarius, S.; Topf, H.G.; Zimmermann, A.; Faas, D.; et al. Neurodevelopmental outcomes of extremely low birthweight infants randomised to different PCO2 targets: The PHELBI follow-up study. Arch. Dis. Child. Fetal Neonatal Ed. 2017, 102, F376-F382. [CrossRef]

96. Askie, L.M.; Henderson-Smart, D.J.; Irwig, L.; Simpson, J.M. Oxygen-saturation targets and outcomes in extremely preterm infants. N. Engl. J. Med. 2003, 349, 959-967. [CrossRef]

97. Askie, L.M.; Darlow, B.A.; Finer, N.; Schmidt, B.; Stenson, B.; Tarnow-Mordi, W.; Davis, P.G.; Carlo, W.A.; Brocklehurst, P.; Davies, L.C.; et al. Association Between Oxygen Saturation Targeting and Death or Disability in Extremely Preterm Infants in the Neonatal Oxygenation Prospective Meta-analysis Collaboration. JAMA 2018, 319, 2190-2201. [CrossRef] [PubMed]

98. Mitra, S.; Singh, B.; El-Naggar, W.; McMillan, D.D. Automated versus manual control of inspired oxygen to target oxygen saturation in preterm infants: A systematic review and meta-analysis. J. Perinatol. 2018, 38, 351-360. [CrossRef] [PubMed]

99. Kallio, M.; Koskela, U.; Peltoniemi, O.; Kontiokari, T.; Pokka, T.; Suo-Palosaari, M.; Saarela, T. Neurally adjusted ventilatory assist (NAVA) in preterm newborn infants with respiratory distress syndrome-a randomized controlled trial. Eur. J. Pediatr. 2016, 175, 1175-1183. [CrossRef]

100. Robbins, M.; Trittmann, J.; Martin, E.; Reber, K.M.; Nelin, L.; Shepherd, E. Early extubation attempts reduce length of stay in extremely preterm infants even if re-intubation is necessary. J. Neonatal Perinat. Med. 2015, 8, 91-97. [CrossRef]

101. Chawla, S.; Natarajan, G.; Shankaran, S.; Carper, B.; Brion, L.P.; Keszler, M.; Carlo, W.A.; Ambalavanan, N.; Gantz, M.G.; Das, A.; et al. Markers of Successful Extubation in Extremely Preterm Infants, and Morbidity After Failed Extubation. J. Pediatr. 2017, 189, 113-119 e112. [CrossRef]

102. Manley, B.J.; Doyle, L.W.; Owen, L.S.; Davis, P.G. Extubating Extremely Preterm Infants: Predictors of Success and Outcomes following Failure. J. Pediatr. 2016, 173, 45-49. [CrossRef]

103. Shalish, W.; Latremouille, S.; Papenburg, J.; Sant'Anna, G.M. Predictors of extubation readiness in preterm infants: A systematic review and meta-analysis. Arch. Dis. Child. Fetal Neonatal Ed. 2019, 104, F89-F97. [CrossRef]

104. Ferguson, K.N.; Roberts, C.T.; Manley, B.J.; Davis, P.G. Interventions to Improve Rates of Successful Extubation in Preterm Infants: A Systematic Review and Meta-analysis. JAMA Pediatr. 2017, 171, 165-174. [CrossRef]

105. Wang, C.S.; Kou, Y.F.; Shah, G.B.; Mitchell, R.B.; Johnson, R.F. Tracheostomy in Extremely Preterm Neonates in the United States: A Cross-Sectional Analysis. Laryngoscope 2020, 130, 2056-2062. [CrossRef]

106. Donda, K.; Agyemang, C.O.; Adjetey, N.A.; Agyekum, A.; Princewill, N.; Ayensu, M.; Bray, L.; Yagnik, P.J.; Bhatt, P.; DapaahSiakwan, F. Tracheostomy trends in preterm infants with bronchopulmonary dysplasia in the United States: 2008-2017. Pediatr. Pulmonol. 2021. [CrossRef]

107. Kurata, H.; Ochiai, M.; Inoue, H.; Ichiyama, M.; Yasuoka, K.; Fujiyoshi, J.; Matsushita, Y.; Honjo, S.; Sakai, Y.; Ohga, S.; et al. A nationwide survey on tracheostomy for very-low-birth-weight infants in Japan. Pediatr. Pulmonol. 2019, 54, 53-60. [CrossRef]

108. DeMauro, S.B.; D'Agostino, J.A.; Bann, C.; Bernbaum, J.; Gerdes, M.; Bell, E.F.; Carlo, W.A.; D'Angio, C.T.; Das, A.; Higgins, R.; et al. Developmental outcomes of very preterm infants with tracheostomies. J. Pediatr. 2014, 164, 1303-1310.e2. [CrossRef]

109. Luo, J.; Shepard, S.; Nilan, K.; Wood, A.; Monk, H.M.; Jensen, E.A.; Harrington, A.T.; Maschhoff, K.; Kirpalani, H.; Feng, Z.; et al. Improved growth and developmental activity post tracheostomy in preterm infants with severe BPD. Pediatr. Pulmonol. 2018, 53, 1237-1244. [CrossRef]

110. Wood, W.; Wang, C.S.; Mitchell, R.B.; Shah, G.B.; Johnson, R.F. A Longitudinal Analysis of Outcomes in Tracheostomy Placement Among Preterm Infants. Laryngoscope 2021, 131, 417-422. [CrossRef]

111. Com, G.; Kuo, D.Z.; Bauer, M.L.; Lenker, C.V.; Melguizo-Castro, M.M.; Nick, T.G.; Makris, C.M. Outcomes of children treated with tracheostomy and positive-pressure ventilation at home. Clin. Pediatr. (Phila) 2013, 52, 54-61. [CrossRef]

112. Cristea, A.I.; Carroll, A.E.; Davis, S.D.; Swigonski, N.L.; Ackerman, V.L. Outcomes of children with severe bronchopulmonary dysplasia who were ventilator dependent at home. Pediatrics 2013, 132, e727-e734. [CrossRef] [PubMed]

113. Doyle, L.W.; Halliday, H.L.; Ehrenkranz, R.A.; Davis, P.G.; Sinclair, J.C. An update on the impact of postnatal systemic corticosteroids on mortality and cerebral palsy in preterm infants: Effect modification by risk of bronchopulmonary dysplasia. J. Pediatr. 2014, 165, 1258-1260. [CrossRef] [PubMed]

114. Doyle, L.W.; Cheong, J.L.; Ehrenkranz, R.A.; Halliday, H.L. Late ( $>7$ days) systemic postnatal corticosteroids for prevention of bronchopulmonary dysplasia in preterm infants. Cochrane Database Syst. Rev. 2017, 10, CD001145. [CrossRef] [PubMed] 
115. Doyle, L.W.; Cheong, J.L.; Ehrenkranz, R.A.; Halliday, H.L. Early ( $<8$ days) systemic postnatal corticosteroids for prevention of bronchopulmonary dysplasia in preterm infants. Cochrane Database Syst. Rev. 2017, 10, CD001146. [CrossRef] [PubMed]

116. Zeng, L.; Tian, J.; Song, F.; Li, W.; Jiang, L.; Gui, G.; Zhang, Y.; Ge, L.; Shi, J.; Sun, X.; et al. Corticosteroids for the prevention of bronchopulmonary dysplasia in preterm infants: A network meta-analysis. Arch. Dis. Child. Fetal Neonatal Ed. 2018, 103, F506-F511. [CrossRef] [PubMed]

117. Shaffer, M.L.; Baud, O.; Lacaze-Masmonteil, T.; Peltoniemi, O.M.; Bonsante, F.; Watterberg, K.L. Effect of Prophylaxis for Early Adrenal Insufficiency Using Low-Dose Hydrocortisone in Very Preterm Infants: An Individual Patient Data Meta-Analysis. J. Pediatr. 2019, 207, 136-142.e5. [CrossRef] [PubMed]

118. Onland, W.; Cools, F.; Kroon, A.; Rademaker, K.; Merkus, M.P.; Dijk, P.H.; van Straaten, H.L.; Te Pas, A.B.; Mohns, T.; Bruneel, E.; et al. Effect of Hydrocortisone Therapy Initiated 7 to 14 Days After Birth on Mortality or Bronchopulmonary Dysplasia Among Very Preterm Infants Receiving Mechanical Ventilation: A Randomized Clinical Trial. JAMA 2019, 321, 354-363. [CrossRef]

119. Venkataraman, R.; Kamaluddeen, M.; Hasan, S.U.; Robertson, H.L.; Lodha, A. Intratracheal Administration of BudesonideSurfactant in Prevention of Bronchopulmonary Dysplasia in Very Low Birth Weight Infants: A Systematic Review and MetaAnalysis. Pediatr. Pulmonol. 2017, 52, 968-975. [CrossRef]

120. Shinwell, E.S.; Portnov, I.; Meerpohl, J.J.; Karen, T.; Bassler, D. Inhaled Corticosteroids for Bronchopulmonary Dysplasia: A Meta-analysis. Pediatrics 2016, 138. [CrossRef]

121. Bassler, D.; Plavka, R.; Shinwell, E.S.; Hallman, M.; Jarreau, P.H.; Carnielli, V.; Van den Anker, J.N.; Meisner, C.; Engel, C.; Schwab, M.; et al. Early Inhaled Budesonide for the Prevention of Bronchopulmonary Dysplasia. N. Engl. J. Med. 2015, 373, 1497-1506. [CrossRef]

122. Bassler, D.; Shinwell, E.S.; Hallman, M.; Jarreau, P.H.; Plavka, R.; Carnielli, V.; Meisner, C.; Engel, C.; Koch, A.; Kreutzer, K.; et al. Long-Term Effects of Inhaled Budesonide for Bronchopulmonary Dysplasia. N. Engl. J. Med. 2018, 378, 148-157. [CrossRef]

123. Zheng, Y.; Xiu, W.; Lin, Y.; Ren, Y.; Zhang, B.; Yang, C. Long-term effects of the intratracheal administration of corticosteroids for the prevention of bronchopulmonary dysplasia: A meta-analysis. Pediatr. Pulmonol. 2019, 54, 1722-1734. [CrossRef]

124. Jakkula, M.; Le Cras, T.D.; Gebb, S.; Hirth, K.P.; Tuder, R.M.; Voelkel, N.F.; Abman, S.H. Inhibition of angiogenesis decreases alveolarization in the developing rat lung. Am. J. Physiol. Lung Cell Mol. Physiol. 2000, 279, L600-L607. [CrossRef] [PubMed]

125. Mourani, P.M.; Mandell, E.W.; Meier, M.; Younoszai, A.; Brinton, J.T.; Wagner, B.D.; Arjaans, S.; Poindexter, B.B.; Abman, S.H. Early Pulmonary Vascular Disease in Preterm Infants Is Associated with Late Respiratory Outcomes in Childhood. Am. J. Respir. Crit. Care Med. 2019, 199, 1020-1027. [CrossRef] [PubMed]

126. Afshar, S.; Gibson, L.L.; Yuhanna, I.S.; Sherman, T.S.; Kerecman, J.D.; Grubb, P.H.; Yoder, B.A.; McCurnin, D.C.; Shaul, P.W. Pulmonary NO synthase expression is attenuated in a fetal baboon model of chronic lung disease. Am. J. Physiol. Lung Cell Mol. Physiol. 2003, 284, L749-L758. [CrossRef] [PubMed]

127. Askie, L.M.; Ballard, R.A.; Cutter, G.R.; Dani, C.; Elbourne, D.; Field, D.; Hascoet, J.M.; Hibbs, A.M.; Kinsella, J.P.; Mercier, J.C.; et al. Inhaled nitric oxide in preterm infants: An individual-patient data meta-analysis of randomized trials. Pediatrics 2011, 128, 729-739. [CrossRef] [PubMed]

128. Cole, F.S.; Alleyne, C.; Barks, J.D.; Boyle, R.J.; Carroll, J.L.; Dokken, D.; Edwards, W.H.; Georgieff, M.; Gregory, K.; Johnston, M.V.; et al. NIH Consensus Development Conference statement: Inhaled nitric-oxide therapy for premature infants. Pediatrics 2011, 127, 363-369. [CrossRef] [PubMed]

129. Donohue, P.K.; Gilmore, M.M.; Cristofalo, E.; Wilson, R.F.; Weiner, J.Z.; Lau, B.D.; Robinson, K.A.; Allen, M.C. Inhaled nitric oxide in preterm infants: A systematic review. Pediatrics 2011, 127, e414-e422. [CrossRef] [PubMed]

130. Allen, M.C.; Donohue, P.; Gilmore, M.; Cristofalo, E.; Wilson, R.F.; Weiner, J.Z.; Robinson, K. Inhaled nitric oxide in preterm infants. Evid. Rep. Technol. Assess. (Full Rep.) 2010, 195, 1-135.

131. Barrington, K.J.; Finer, N.; Pennaforte, T. Inhaled nitric oxide for respiratory failure in preterm infants. Cochrane Database Syst. Rev. 2017, 1, CD000509. [CrossRef]

132. Hasan, S.U.; Potenziano, J.; Konduri, G.G.; Perez, J.A.; Van Meurs, K.P.; Walker, M.W.; Yoder, B.A.; The Newborns Treated With Nitric Oxide (NEWNO) Trial Group. Effect of Inhaled Nitric Oxide on Survival Without Bronchopulmonary Dysplasia in Preterm Infants: A Randomized Clinical Trial. JAMA Pediatr. 2017, 171, 1081-1089. [CrossRef] [PubMed]

133. Askie, L.M.; Davies, L.C.; Schreiber, M.D.; Hibbs, A.M.; Ballard, P.L.; Ballard, R.A. Race Effects of Inhaled Nitric Oxide in Preterm Infants: An Individual Participant Data Meta-Analysis. J. Pediatr. 2018, 193, 34-39.e2. [CrossRef] [PubMed]

134. Rotschild, A.; Solimano, A.; Puterman, M.; Smyth, J.; Sharma, A.; Albersheim, S. Increased compliance in response to salbutamol in premature infants with developing bronchopulmonary dysplasia. J. Pediatr. 1989, 115, 984-991. [CrossRef]

135. Khalaf, M.N.; Hurley, J.F.; Bhandari, V. A prospective controlled trial of albuterol aerosol delivered via metered dose inhaler-spacer device (MDI) versus jet nebulizer in ventilated preterm neonates. Am. J. Perinatol. 2001, 18, 169-174. [CrossRef] [PubMed]

136. Pfenninger, J.; Aebi, C. Respiratory response to salbutamol (albuterol) in ventilator-dependent infants with chronic lung disease: Pressurized aerosol delivery versus intravenous injection. Intensive Care Med. 1993, 19, 251-255. [CrossRef] [PubMed]

137. Ng, G.; da Silva, O.; Ohlsson, A. Bronchodilators for the prevention and treatment of chronic lung disease in preterm infants. Cochrane Database Syst. Rev. 2016, 12, CD003214. [CrossRef] [PubMed] 
138. Armanian, A.M.; Badiee, Z.; Afghari, R.; Salehimehr, N.; Hassanzade, A.; Sheikhzadeh, S.; Shariftehrani, M.; Rezvan, G. Reducing the incidence of chronic lung disease in very premature infants with aminophylline. Int. J. Prev. Med. 2014, 5, 569-576.

139. Denjean, A.; Paris-Llado, J.; Zupan, V.; Debillon, T.; Kieffer, F.; Magny, J.F.; Desfreres, L.; Llanas, B.; Guimaraes, H.; Moriette, G.; et al. Inhaled salbutamol and beclomethasone for preventing broncho-pulmonary dysplasia: A randomised double-blind study. Eur. J. Pediatr. 1998, 157, 926-931. [CrossRef]

140. Clouse, B.J.; Jadcherla, S.R.; Slaughter, J.L. Systematic Review of Inhaled Bronchodilator and Corticosteroid Therapies in Infants with Bronchopulmonary Dysplasia: Implications and Future Directions. PLoS ONE 2016, 11, e0148188. [CrossRef]

141. Euteneuer, J.C.; Kerns, E.; Leiting, C.; McCulloh, R.J.; Peeples, E.S. Inhaled bronchodilator exposure in the management of bronchopulmonary dysplasia in hospitalized infants. J. Perinatol. 2021, 41, 53-61. [CrossRef]

142. Chu, A.; de St Maurice, A.; Sim, M.S.; Kallapur, S.G. Neonatal Mycoplasma and Ureaplasma Infections. Pediatr. Ann. 2020, 49, e305-e312. [CrossRef] [PubMed]

143. Wang, E.E.; Ohlsson, A.; Kellner, J.D. Association of Ureaplasma urealyticum colonization with chronic lung disease of prematurity: Results of a metaanalysis. J. Pediatr. 1995, 127, 640-644. [CrossRef]

144. Schelonka, R.L.; Katz, B.; Waites, K.B.; Benjamin, D.K., Jr. Critical appraisal of the role of Ureaplasma in the development of bronchopulmonary dysplasia with metaanalytic techniques. Pediatr. Infect. Dis. J. 2005, 24, 1033-1039. [CrossRef] [PubMed]

145. Pammi, M.; Lal, C.V.; Wagner, B.D.; Mourani, P.M.; Lohmann, P.; Luna, R.A.; Sisson, A.; Shivanna, B.; Hollister, E.B.; Abman, S.H.; et al. Airway Microbiome and Development of Bronchopulmonary Dysplasia in Preterm Infants: A Systematic Review. J. Pediatr. 2019, 204, 126-133.e2. [CrossRef] [PubMed]

146. Glaser, K.; Gradzka-Luczewska, A.; Szymankiewicz-Breborowicz, M.; Kawczynska-Leda, N.; Henrich, B.; Waaga-Gasser, A.M.; Speer, C.P. Perinatal Ureaplasma Exposure Is Associated With Increased Risk of Late Onset Sepsis and Imbalanced Inflammation in Preterm Infants and May Add to Lung Injury. Front. Cell. Infect. Microbiol. 2019, 9, 68. [CrossRef] [PubMed]

147. Lowe, J.; Watkins, W.J.; Edwards, M.O.; Spiller, O.B.; Jacqz-Aigrain, E.; Kotecha, S.J.; Kotecha, S. Association between pulmonary ureaplasma colonization and bronchopulmonary dysplasia in preterm infants: Updated systematic review and meta-analysis. Pediatr. Infect. Dis. J. 2014, 33, 697-702. [CrossRef]

148. Viscardi, R.M.; Kallapur, S.G. Role of Ureaplasma Respiratory Tract Colonization in Bronchopulmonary Dysplasia Pathogenesis: Current Concepts and Update. Clin. Perinatol. 2015, 42, 719-738. [CrossRef]

149. Mabanta, C.G.; Pryhuber, G.S.; Weinberg, G.A.; Phelps, D.L. Erythromycin for the prevention of chronic lung disease in intubated preterm infants at risk for, or colonized or infected with Ureaplasma urealyticum. Cochrane Database Syst. Rev. 2003, CD003744. [CrossRef]

150. Nair, V.; Loganathan, P.; Soraisham, A.S. Azithromycin and other macrolides for prevention of bronchopulmonary dysplasia: A systematic review and meta-analysis. Neonatology 2014, 106, 337-347. [CrossRef]

151. Razak, A.; Alshehri, N. Azithromycin for preventing bronchopulmonary dysplasia in preterm infants: A systematic review and meta-analysis. Pediatr. Pulmonol. 2020, 31, 31. [CrossRef]

152. Lowe, J.; Gillespie, D.; Hubbard, M.; Zhang, L.; Kirby, N.; Pickles, T.; Thomas-Jones, E.; Turner, M.A.; Klein, N.; Marchesi, J.R.; et al. Study protocol: Azithromycin therapy for chronic lung disease of prematurity (AZTEC)—A randomised, placebo-controlled trial of azithromycin for the prevention of chronic lung disease of prematurity in preterm infants. BMJ Open 2020, 10, e041528. [CrossRef] [PubMed]

153. Piersigilli, F.; Van Grambezen, B.; Hocq, C.; Danhaive, O. Nutrients and Microbiota in Lung Diseases of Prematurity: The Placenta-Gut-Lung Triangle. Nutrients 2020, 12, 469. [CrossRef] [PubMed]

154. Ting, J.Y.; Synnes, A.; Roberts, A.; Deshpandey, A.; Dow, K.; Yoon, E.W.; Lee, K.S.; Dobson, S.; Lee, S.K.; Shah, P.S.; et al. Association Between Antibiotic Use and Neonatal Mortality and Morbidities in Very Low-Birth-Weight Infants Without Culture-Proven Sepsis or Necrotizing Enterocolitis. JAMA Pediatr. 2016, 170, 1181-1187. [CrossRef] [PubMed]

155. Mukhopadhyay, S.; Sengupta, S.; Puopolo, K.M. Challenges and opportunities for antibiotic stewardship among preterm infants. Arch. Dis. Child. Fetal Neonatal Ed. 2019, 104, F327-F332. [CrossRef] [PubMed]

156. Sung, S.I.; Chang, Y.S.; Kim, J.; Choi, J.H.; Ahn, S.Y.; Park, W.S. Natural evolution of ductus arteriosus with noninterventional conservative management in extremely preterm infants born at 23-28 weeks of gestation. PLoS ONE 2019, 14, e0212256. [CrossRef]

157. Hamrick, S.E.G.; Sallmon, H.; Rose, A.T.; Porras, D.; Shelton, E.L.; Reese, J.; Hansmann, G. Patent Ductus Arteriosus of the Preterm Infant. Pediatrics 2020, 146. [CrossRef]

158. Mitra, S.; McNamara, P.J. Patent Ductus Arteriosus-Time for a Definitive Trial. Clin. Perinatol. 2020, 47, 617-639. [CrossRef] [PubMed]

159. Liu, C.; Zhu, X.; Li, D.; Shi, Y. Related Factors of Patent Ductus Arteriosus in Preterm Infants: A Systematic Review and Meta-Analysis. Front. Pediatr. 2020, 8, 605879. [CrossRef] [PubMed]

160. Hundscheid, T.; Onland, W.; van Overmeire, B.; Dijk, P.; van Kaam, A.; Dijkman, K.P.; Kooi, E.M.W.; Villamor, E.; Kroon, A.A.; Visser, R.; et al. Early treatment versus expectative management of patent ductus arteriosus in preterm infants: A multicentre, randomised, non-inferiority trial in Europe (BeNeDuctus trial). BMC Pediatr. 2018, 18, 262. [CrossRef]

161. Fowlie, P.W.; Davis, P.G.; McGuire, W. Prophylactic intravenous indomethacin for preventing mortality and morbidity in preterm infants. Cochrane Database Syst. Rev. 2010, CD000174. [CrossRef]

162. Evans, P.; O'Reilly, D.; Flyer, J.N.; Soll, R.; Mitra, S. Indomethacin for symptomatic patent ductus arteriosus in preterm infants. Cochrane Database Syst. Rev. 2021, 1, CD013133. [CrossRef] 
163. Ohlsson, A.; Shah, P.S. Paracetamol (acetaminophen) for patent ductus arteriosus in preterm or low birth weight infants. Cochrane Database Syst. Rev. 2020, 1, CD010061. [CrossRef] [PubMed]

164. Ohlsson, A.; Shah, S.S. Ibuprofen for the prevention of patent ductus arteriosus in preterm and/or low birth weight infants. Cochrane Database Syst. Rev. 2020, 1, CD004213. [CrossRef]

165. Ohlsson, A.; Walia, R.; Shah, S.S. Ibuprofen for the treatment of patent ductus arteriosus in preterm or low birth weight (or both) infants. Cochrane Database Syst. Rev. 2020, 2, CD003481. [CrossRef]

166. Mitra, S.; Florez, I.D.; Tamayo, M.E.; Mbuagbaw, L.; Vanniyasingam, T.; Veroniki, A.A.; Zea, A.M.; Zhang, Y.; Sadeghirad, B.; Thabane, L. Association of Placebo, Indomethacin, Ibuprofen, and Acetaminophen With Closure of Hemodynamically Significant Patent Ductus Arteriosus in Preterm Infants: A Systematic Review and Meta-analysis. JAMA 2018, 319, 1221-1238. [CrossRef]

167. Marconi, E.; Bettiol, A.; Ambrosio, G.; Perduca, V.; Vannacci, A.; Troiani, S.; Dani, C.; Mugelli, A.; Lucenteforte, E. Efficacy and safety of pharmacological treatments for patent ductus arteriosus closure: A systematic review and network meta-analysis of clinical trials and observational studies. Pharm. Res. 2019, 148, 104418. [CrossRef] [PubMed]

168. Bixler, G.M.; Powers, G.C.; Clark, R.H.; Walker, M.W.; Tolia, V.N. Changes in the Diagnosis and Management of Patent Ductus Arteriosus from 2006 to 2015 in United States Neonatal Intensive Care Units. J. Pediatr. 2017, 189, 105-112. [CrossRef]

169. Weisz, D.E.; More, K.; McNamara, P.J.; Shah, P.S. PDA ligation and health outcomes: A meta-analysis. Pediatrics 2014, 133, e1024-e1046. [CrossRef]

170. Weisz, D.E.; Mirea, L.; Rosenberg, E.; Jang, M.; Ly, L.; Church, P.T.; Kelly, E.; Kim, S.J.; Jain, A.; McNamara, P.J.; et al. Association of Patent Ductus Arteriosus Ligation With Death or Neurodevelopmental Impairment Among Extremely Preterm Infants. JAMA Pediatr. 2017, 171, 443-449. [CrossRef] [PubMed]

171. Backes, C.H.; Rivera, B.K.; Bridge, J.A.; Armstrong, A.K.; Boe, B.A.; Berman, D.P.; Fick, T.; Holzer, R.J.; Hijazi, Z.M.; Abadir, S.; et al. Percutaneous Patent Ductus Arteriosus (PDA) Closure During Infancy: A Meta-analysis. Pediatrics 2017, 139. [CrossRef]

172. Sathanandam, S.K.; Gutfinger, D.; O’Brien, L.; Forbes, T.J.; Gillespie, M.J.; Berman, D.P.; Armstrong, A.K.; Shahanavaz, S.; Jones, T.K.; Morray, B.H.; et al. Amplatzer Piccolo Occluder clinical trial for percutaneous closure of the patent ductus arteriosus in patients $>/=700$ grams. Catheter. Cardiovasc. Interv. 2020, 96, 1266-1276. [CrossRef]

173. Semberova, J.; Sirc, J.; Miletin, J.; Kucera, J.; Berka, I.; Sebkova, S.; O’Sullivan, S.; Franklin, O.; Stranak, Z. Spontaneous Closure of Patent Ductus Arteriosus in Infants $</=1500$ g. Pediatrics 2017, 140. [CrossRef]

174. Mitra, S.; Scrivens, A.; von Kursell, A.M.; Disher, T. Early treatment versus expectant management of hemodynamically significant patent ductus arteriosus for preterm infants. Cochrane Database Syst. Rev. 2020, 12, CD013278. [CrossRef]

175. Sung, S.I.; Chang, Y.S.; Ahn, S.Y.; Jo, H.S.; Yang, M.; Park, W.S. Conservative Non-intervention Approach for Hemodynamically Significant Patent Ductus Arteriosus in Extremely Preterm Infants. Front. Pediatr. 2020, 8, 605134. [CrossRef]

176. Letshwiti, J.B.; Semberova, J.; Pichova, K.; Dempsey, E.M.; Franklin, O.M.; Miletin, J. A conservative treatment of patent ductus arteriosus in very low birth weight infants. Early Hum. Dev. 2017, 104, 45-49. [CrossRef]

177. Clyman, R.I.; Hills, N.K.; Liebowitz, M.; Johng, S. Relationship between Duration of Infant Exposure to a Moderate-to-Large Patent Ductus Arteriosus Shunt and the Risk of Developing Bronchopulmonary Dysplasia or Death Before 36 Weeks. Am. J. Perinatol. 2020, 37, 216-223. [CrossRef]

178. Stephens, B.E.; Gargus, R.A.; Walden, R.V.; Mance, M.; Nye, J.; McKinley, L.; Tucker, R.; Vohr, B.R. Fluid regimens in the first week of life may increase risk of patent ductus arteriosus in extremely low birth weight infants. J. Perinatol. 2008, 28, 123-128. [CrossRef] [PubMed]

179. Bell, E.F.; Acarregui, M.J. Restricted versus liberal water intake for preventing morbidity and mortality in preterm infants. Cochrane Database Syst. Rev. 2014, CD000503. [CrossRef] [PubMed]

180. Barrington, K.J.; Fortin-Pellerin, E.; Pennaforte, T. Fluid restriction for treatment of preterm infants with chronic lung disease. Cochrane Database Syst. Rev. 2017, 2, CD005389. [CrossRef]

181. Oh, W.; Poindexter, B.B.; Perritt, R.; Lemons, J.A.; Bauer, C.R.; Ehrenkranz, R.A.; Stoll, B.J.; Poole, K.; Wright, L.L.; Neonatal Research Network. Association between fluid intake and weight loss during the first ten days of life and risk of bronchopulmonary dysplasia in extremely low birth weight infants. J. Pediatr. 2005, 147, 786-790. [CrossRef]

182. Marshall, D.D.; Kotelchuck, M.; Young, T.E.; Bose, C.L.; Kruyer, L.; O'Shea, T.M. Risk factors for chronic lung disease in the surfactant era: A North Carolina population-based study of very low birth weight infants. North Carolina Neonatologists Association. Pediatrics 1999, 104, 1345-1350. [CrossRef]

183. Wemhoner, A.; Ortner, D.; Tschirch, E.; Strasak, A.; Rudiger, M. Nutrition of preterm infants in relation to bronchopulmonary dysplasia. BMC Pulm. Med. 2011, 11, 7. [CrossRef]

184. Uberos, J.; Jimenez-Montilla, S.; Molina-Oya, M.; Garcia-Serrano, J.L. Early energy restriction in premature infants and bronchopulmonary dysplasia: A cohort study. Br. J. Nutr. 2020, 123, 1024-1031. [CrossRef]

185. Greenberg, J.M.; Poindexter, B.B.; Shaw, P.A.; Bellamy, S.L.; Keller, R.L.; Moore, P.E.; McPherson, C.; Ryan, R.M. Respiratory medication use in extremely premature ( $<29$ weeks) infants during initial NICU hospitalization: Results from the prematurity and respiratory outcomes program. Pediatr. Pulmonol. 2020, 55, 360-368. [CrossRef]

186. Bamat, N.A.; Nelin, T.D.; Eichenwald, E.C.; Kirpalani, H.; Laughon, M.M.; Jackson, W.M.; Jensen, E.A.; Gibbs, K.A.; Lorch, S.A. Loop Diuretics in Severe Bronchopulmonary Dysplasia: Cumulative Use and Associations with Mortality and Age at Discharge. J. Pediatr. 2020. [CrossRef] 
187. Brion, L.P.; Primhak, R.A.; Yong, W. Aerosolized diuretics for preterm infants with (or developing) chronic lung disease. Cochrane Database Syst. Rev. 2006, CD001694. [CrossRef]

188. Stewart, A.; Brion, L.P. Intravenous or enteral loop diuretics for preterm infants with (or developing) chronic lung disease. Cochrane Database Syst. Rev. 2011, CD001453. [CrossRef]

189. Stewart, A.; Brion, L.P.; Ambrosio-Perez, I. Diuretics acting on the distal renal tubule for preterm infants with (or developing) chronic lung disease. Cochrane Database Syst. Rev. 2011, CD001817. [CrossRef] [PubMed]

190. Greenberg, R.G.; Gayam, S.; Savage, D.; Tong, A.; Gorham, D.; Sholomon, A.; Clark, R.H.; Benjamin, D.K.; Laughon, M.; Smith, P.B.; et al. Furosemide Exposure and Prevention of Bronchopulmonary Dysplasia in Premature Infants. J. Pediatr. 2019, 208, 134-140.e2. [CrossRef]

191. Pacifici, G.M. Clinical pharmacology of furosemide in neonates: A review. Pharmaceuticals (Basel) 2013, 6, 1094-1129. [CrossRef] [PubMed]

192. de Meer, K.; Westerterp, K.R.; Houwen, R.H.; Brouwers, H.A.; Berger, R.; Okken, A. Total energy expenditure in infants with bronchopulmonary dysplasia is associated with respiratory status. Eur. J. Pediatr. 1997, 156, 299-304. [CrossRef] [PubMed]

193. Malikiwi, A.I.; Lee, Y.M.; Davies-Tuck, M.; Wong, F.Y. Postnatal nutritional deficit is an independent predictor of bronchopulmonary dysplasia among extremely premature infants born at or less than 28weeks gestation. Early Hum. Dev. 2019, 131, 29-35. [CrossRef]

194. Lai, N.M.; Rajadurai, S.V.; Tan, K.H. Increased energy intake for preterm infants with (or developing) bronchopulmonary dysplasia/chronic lung disease. Cochrane Database Syst. Rev. 2006, CD005093. [CrossRef] [PubMed]

195. Milanesi, B.G.; Lima, P.A.; Villela, L.D.; Martins, A.S.; Gomes-Junior, S.C.S.; Moreira, M.E.L.; Meio, M. Assessment of early nutritional intake in preterm infants with bronchopulmonary dysplasia: A cohort study. Eur. J. Pediatr. 2021. [CrossRef] [PubMed]

196. Ding, L.; Wang, H.; Geng, H.; Cui, N.; Huang, F.; Zhu, X.; Zhu, X. Prediction of Bronchopulmonary Dysplasia in Preterm Infants Using Postnatal Risk Factors. Front. Pediatr. 2020, 8, 349. [CrossRef] [PubMed]

197. Moschino, L.; Duci, M.; Fascetti Leon, F.; Bonadies, L.; Priante, E.; Baraldi, E.; Verlato, G. Optimizing Nutritional Strategies to Prevent Necrotizing Enterocolitis and Growth Failure after Bowel Resection. Nutrients 2021, 13, 340. [CrossRef] [PubMed]

198. Villamor-Martinez, E.; Pierro, M.; Cavallaro, G.; Mosca, F.; Kramer, B.W.; Villamor, E. Donor Human Milk Protects against Bronchopulmonary Dysplasia: A Systematic Review and Meta-Analysis. Nutrients 2018, 10, 238. [CrossRef]

199. Huang, J.; Zhang, L.; Tang, J.; Shi, J.; Qu, Y.; Xiong, T.; Mu, D. Human milk as a protective factor for bronchopulmonary dysplasia: A systematic review and meta-analysis. Arch. Dis. Child. Fetal Neonatal Ed. 2019, 104, F128-F136. [CrossRef]

200. Villamor-Martinez, E.; Pierro, M.; Cavallaro, G.; Mosca, F.; Villamor, E. Mother's Own Milk and Bronchopulmonary Dysplasia: A Systematic Review and Meta-Analysis. Front. Pediatr. 2019, 7, 224. [CrossRef]

201. Arslanoglu, S.; Boquien, C.Y.; King, C.; Lamireau, D.; Tonetto, P.; Barnett, D.; Bertino, E.; Gaya, A.; Gebauer, C.; Grovslien, A.; et al. Fortification of Human Milk for Preterm Infants: Update and Recommendations of the European Milk Bank Association (EMBA) Working Group on Human Milk Fortification. Front. Pediatr. 2019, 7, 76. [CrossRef]

202. Fabrizio, V.; Trzaski, J.M.; Brownell, E.A.; Esposito, P.; Lainwala, S.; Lussier, M.M.; Hagadorn, J.I. Individualized versus standard diet fortification for growth and development in preterm infants receiving human milk. Cochrane Database Syst. Rev. 2020, 11, CD013465. [CrossRef]

203. Jain, D.; Bancalari, E. Prevention of bronchopulmonary dysplasia: Current strategies. Zhongguo Dang Dai Er Ke Za Zhi 2017, 19, 841-851.

204. Shenai, J.P.; Kennedy, K.A.; Chytil, F.; Stahlman, M.T. Clinical trial of vitamin A supplementation in infants susceptible to bronchopulmonary dysplasia. J. Pediatr. 1987, 111, 269-277. [CrossRef]

205. Ding, Y.; Chen, Z.; Lu, Y. Vitamin A supplementation prevents the bronchopulmonary dysplasia in premature infants: A systematic review and meta-analysis. Medicine (Baltimore) 2021, 100, e23101. [CrossRef]

206. Hustead, V.A.; Gutcher, G.R.; Anderson, S.A.; Zachman, R.D. Relationship of vitamin A (retinol) status to lung disease in the preterm infant. J. Pediatr. 1984, 105, 610-615. [CrossRef]

207. Darlow, B.A.; Graham, P.J.; Rojas-Reyes, M.X. Vitamin A supplementation to prevent mortality and short- and long-term morbidity in very low birth weight infants. Cochrane Database Syst. Rev. 2016, CD000501. [CrossRef] [PubMed]

208. Araki, S.; Kato, S.; Namba, F.; Ota, E. Vitamin A to prevent bronchopulmonary dysplasia in extremely low birth weight infants: A systematic review and meta-analysis. PLoS ONE 2018, 13, e0207730. [CrossRef]

209. Garg, B.D.; Bansal, A.; Kabra, N.S. Role of vitamin A supplementation in prevention of bronchopulmonary dysplasia in extremely low birth weight neonates: A systematic review of randomized trials. J. Matern. Fetal Neonatal Med. 2019, 32, 2608-2615. [CrossRef] [PubMed]

210. Tolia, V.N.; Murthy, K.; McKinley, P.S.; Bennett, M.M.; Clark, R.H. The effect of the national shortage of vitamin A on death or chronic lung disease in extremely low-birth-weight infants. JAMA Pediatrics 2014, 168, 1039-1044. [CrossRef] [PubMed]

211. Rakshasbhuvankar, A.A.; Simmer, K.; Patole, S.K.; Stoecklin, B.; Nathan, E.A.; Clarke, M.W.; Pillow, J.J. Enteral Vitamin A for Reducing Severity of Bronchopulmonary Dysplasia: A Randomized Trial. Pediatrics 2021, 147. [CrossRef] [PubMed]

212. Basu, S.; Khanna, P.; Srivastava, R.; Kumar, A. Oral vitamin A supplementation in very low birth weight neonates: A randomized controlled trial. Eur. J. Pediatr. 2019, 178, 1255-1265. [CrossRef] 
213. Tyson, J.E.; Wright, L.L.; Oh, W.; Kennedy, K.A.; Mele, L.; Ehrenkranz, R.A.; Stoll, B.J.; Lemons, J.A.; Stevenson, D.K.; Bauer, C.R.; et al. Vitamin A supplementation for extremely-low-birth-weight infants. National Institute of Child Health and Human Development Neonatal Research Network. N. Engl. J. Med. 1999, 340, 1962-1968. [CrossRef]

214. Sun, H.; Cheng, R.; Wang, Z. Early Vitamin a Supplementation Improves the Outcome of Retinopathy of Prematurity in Extremely Preterm Infants. Retina 2020, 40, 1176-1184. [CrossRef]

215. Meyer, S.; Gortner, L.; NeoVitaA Trial investigators. Up-date on the NeoVitaA Trial: Obstacles, challenges, perspectives, and local experiences. Wien. Med. Wochenschr. 2017, 167, 264-270. [CrossRef] [PubMed]

216. Calisici, E.; Yarci, E.; Degirmencioglu, H.; Oncel, M.; Oguz, S.; Uras, N.; Dilmen, U. PO-0731 The Effects of Early Oral Vitamin a Treatment on the Prevention of Bronchopulmonary Displasia in the Low Birth Weight Infants. Arch. Dis. Child. 2014, 99, A494. [CrossRef]

217. Meyer, S.; Kronfeld, K.; Graber, S.; Butzer, R.; Wahl, H.; Gortner, L. Vitamin A to prevent bronchopulmonary dysplasia: The NeoVitaA trial. J. Matern. Fetal Neonatal Med. 2013, 26, 544-545. [CrossRef]

218. Kumar, V.H.S. Diagnostic Approach to Pulmonary Hypertension in Premature Neonates. Children (Basel) 2017, 4, 75. [CrossRef] [PubMed]

219. Arjaans, S.; Zwart, E.A.H.; Ploegstra, M.J.; Bos, A.F.; Kooi, E.M.W.; Hillege, H.L.; Berger, R.M.F. Identification of gaps in the current knowledge on pulmonary hypertension in extremely preterm infants: A systematic review and meta-analysis. Paediatr. Perinat. Epidemiol. 2018, 32, 258-267. [CrossRef]

220. Al-Ghanem, G.; Shah, P.; Thomas, S.; Banfield, L.; El Helou, S.; Fusch, C.; Mukerji, A. Bronchopulmonary dysplasia and pulmonary hypertension: A meta-analysis. J. Perinatol. 2017, 37, 414-419. [CrossRef]

221. Lagatta, J.M.; Hysinger, E.B.; Zaniletti, I.; Wymore, E.M.; Vyas-Read, S.; Yallapragada, S.; Nelin, L.D.; Truog, W.E.; Padula, M.A.; Porta, N.F.M.; et al. The Impact of Pulmonary Hypertension in Preterm Infants with Severe Bronchopulmonary Dysplasia through 1 Year. J. Pediatr. 2018, 203, 218-224 e213. [CrossRef]

222. Arjaans, S.; Haarman, M.G.; Roofthooft, M.T.R.; Fries, M.W.F.; Kooi, E.M.W.; Bos, A.F.; Berger, R.M.F. Fate of pulmonary hypertension associated with bronchopulmonary dysplasia beyond 36 weeks postmenstrual age. Arch. Dis. Child. Fetal Neonatal Ed. 2021, 106, 45-50. [CrossRef]

223. Altit, G.; Bhombal, S.; Hopper, R.K.; Tacy, T.A.; Feinstein, J. Death or resolution: The "natural history" of pulmonary hypertension in bronchopulmonary dysplasia. J. Perinatol. 2019, 39, 415-425. [CrossRef] [PubMed]

224. Mourani, P.M.; Sontag, M.K.; Younoszai, A.; Miller, J.I.; Kinsella, J.P.; Baker, C.D.; Poindexter, B.B.; Ingram, D.A.; Abman, S.H. Early pulmonary vascular disease in preterm infants at risk for bronchopulmonary dysplasia. Am. J. Respir. Crit. Care Med. 2015, 191, 87-95. [CrossRef] [PubMed]

225. Hilgendorff, A.; Apitz, C.; Bonnet, D.; Hansmann, G. Pulmonary hypertension associated with acute or chronic lung diseases in the preterm and term neonate and infant. The European Paediatric Pulmonary Vascular Disease Network, endorsed by ISHLT and DGPK. Heart 2016, 102 (Suppl. 2), ii49-ii56. [CrossRef] [PubMed]

226. Hansmann, G.; Koestenberger, M.; Alastalo, T.P.; Apitz, C.; Austin, E.D.; Bonnet, D.; Budts, W.; D'Alto, M.; Gatzoulis, M.A.; Hasan, B.S.; et al. 2019 updated consensus statement on the diagnosis and treatment of pediatric pulmonary hypertension: The European Pediatric Pulmonary Vascular Disease Network (EPPVDN), endorsed by AEPC, ESPR and ISHLT. J. Heart Lung Transplant. 2019, 38, 879-901. [CrossRef] [PubMed]

227. Baczynski, M.; Kelly, E.; McNamara, P.J.; Shah, P.S.; Jain, A. Short and long-term outcomes of chronic pulmonary hypertension in preterm infants managed using a standardized algorithm. Pediatr. Pulmonol. 2020. [CrossRef]

228. Laliberte, C.; Hanna, Y.; Ben Fadel, N.; Lemyre, B.; Bijelic, V.; Barrowman, N.; Hoey, L.; Thebaud, B.; Katz, S.L. Target oxygen saturation and development of pulmonary hypertension and increased pulmonary vascular resistance in preterm infants. Pediatr. Pulmonol. 2019, 54, 73-81. [CrossRef]

229. Chandrasekharan, P.; Lakshminrusimha, S. Oxygen therapy in preterm infants with pulmonary hypertension. Semin. Fetal Neonatal Med. 2020, 25, 101070. [CrossRef]

230. Laux, D.; Rocchisani, M.A.; Boudjemline, Y.; Gouton, M.; Bonnet, D.; Ovaert, C. Pulmonary Hypertension in the Preterm Infant with Chronic Lung Disease can be Caused by Pulmonary Vein Stenosis: A Must-Know Entity. Pediatr. Cardiol. 2016, 37, 313-321. [CrossRef]

231. van der Graaf, M.; Rojer, L.A.; Helbing, W.; Reiss, I.; Etnel, J.R.G.; Bartelds, B. EXPRESS: Sildenafil for bronchopulmonary dysplasia and pulmonary hypertension: A meta-analysis. Pulm. Circ. 2019, 2045894019837875. [CrossRef]

232. FDA. Drug Safety Communication: FDA Recommends against Use of Revatio (Sildenafil) in Children With pulmonary Hypertension; FDA: Silver Spring, MD, USA, 2012.

233. Unegbu, C.; Noje, C.; Coulson, J.D.; Segal, J.B.; Romer, L. Pulmonary Hypertension Therapy and a Systematic Review of Efficacy and Safety of PDE-5 Inhibitors. Pediatrics 2017, 139. [CrossRef]

234. Nitkin, C.R.; Rajasingh, J.; Pisano, C.; Besner, G.E.; Thebaud, B.; Sampath, V. Stem cell therapy for preventing neonatal diseases in the 21st century: Current understanding and challenges. Pediatr. Res. 2020, 87, 265-276. [CrossRef] [PubMed]

235. Augustine, S.; Cheng, W.; Avey, M.T.; Chan, M.L.; Lingappa, S.M.C.; Hutton, B.; Thebaud, B. Are all stem cells equal? Systematic review, evidence map, and meta-analyses of preclinical stem cell-based therapies for bronchopulmonary dysplasia. Stem. Cells Transl. Med. 2020, 9, 158-168. [CrossRef] [PubMed] 
236. Namba, F. Mesenchymal stem cells for the prevention of bronchopulmonary dysplasia. Pediatr. Int. 2019, 61, 945-950. [CrossRef]

237. Augustine, S.; Avey, M.T.; Harrison, B.; Locke, T.; Ghannad, M.; Moher, D.; Thebaud, B. Mesenchymal Stromal Cell Therapy in Bronchopulmonary Dysplasia: Systematic Review and Meta-Analysis of Preclinical Studies. Stem. Cells Transl. Med. 2017, 6, 2079-2093. [CrossRef]

238. Obendorf, J.; Fabian, C.; Thome, U.H.; Laube, M. Paracrine stimulation of perinatal lung functional and structural maturation by mesenchymal stem cells. Stem. Cell Res. Ther. 2020, 11, 525. [CrossRef]

239. Chang, Y.S.; Ahn, S.Y.; Yoo, H.S.; Sung, S.I.; Choi, S.J.; Oh, W.I.; Park, W.S. Mesenchymal stem cells for bronchopulmonary dysplasia: Phase 1 dose-escalation clinical trial. J. Pediatr. 2014, 164, 966-972.e6. [CrossRef] [PubMed]

240. Ahn, S.Y.; Chang, Y.S.; Kim, J.H.; Sung, S.I.; Park, W.S. Two-Year Follow-Up Outcomes of Premature Infants Enrolled in the Phase I Trial of Mesenchymal Stem Cells Transplantation for Bronchopulmonary Dysplasia. J. Pediatr. 2017, 185, 49-54.e2. [CrossRef] [PubMed]

241. van Kaam, A.H.; De Jaegere, A.P.; Rimensberger, P.C.; Neovent Study Group. Incidence of hypo- and hyper-capnia in a cross-sectional European cohort of ventilated newborn infants. Arch. Dis. Child. Fetal Neonatal Ed. 2013, 98, F323-F326. [CrossRef]

242. Bronsky, J.; Campoy, C.; Braegger, C.; The ESPGHAN/ESPEN/ESPR/CSPEN Working Group on Pediatric Parenteral Nutrition. ESPGHAN/ESPEN/ESPR/CSPEN guidelines on pediatric parenteral nutrition: Vitamins. Clin. Nutr. 2018, 37, 2366-2378. [CrossRef]

243. Agostoni, C.; Buonocore, G.; Carnielli, V.P.; De Curtis, M.; Darmaun, D.; Decsi, T.; Domellof, M.; Embleton, N.D.; Fusch, C.; Genzel-Boroviczeny, O.; et al. Enteral nutrient supply for preterm infants: Commentary from the European Society of Paediatric Gastroenterology, Hepatology and Nutrition Committee on Nutrition. J. Pediatr. Gastroenterol. Nutr. 2010, 50, 85-91. [CrossRef] [PubMed] 